\title{
CORPORATE GOVERNANCE AND EXECUTIVE PAY: EVIDENCE FROM A RECENT REFORM
}

\section{Teodora Paligorova}
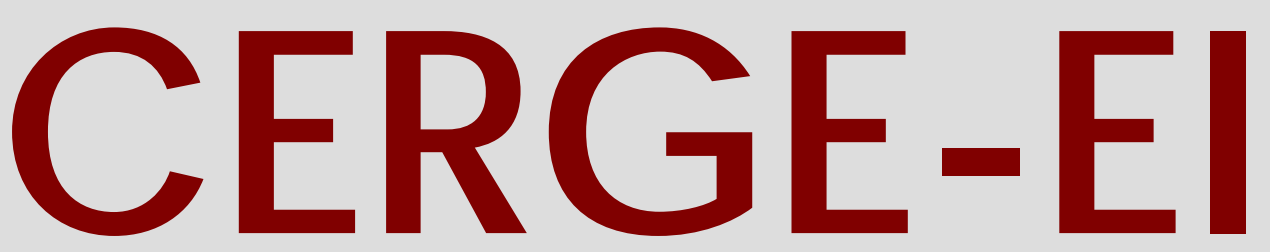

Charles University Centerfor Economic Research and Graduate Education Academy of Sciences of the Czech Republic Ec onomic Institute 


\title{
Working Paper Series 331 (ISSN 1211-3298)
}

\section{Corporate Governance and Executive Pay: Evidence from a Recent Reform}

\author{
Teodora Paligorova
}

CERGE-EI

Prague, July 2007 
ISBN 978-80-7343-130-3 (Univerzita Karlova. Centrum pro ekonomický výzkum a doktorské studium)

ISBN 978-80-7344-119-7 (Národohospodářský ústav AV ČR, v.v.i.) 


\title{
Corporate Governance and Executive Pay: Evidence from a Recent Reform
}

\author{
Teodora Paligorova*
}

CERGE-EI ${ }^{+}$

\begin{abstract}
I examine the effect of the Sarbanes-Oxley Act of 2002 (SOX) on the structure of executive pay. Specifically, I consider the increased board oversight implied by SOX, which is expected to weaken the pay-for-performance link under traditional agency models. Alternatively, if entrenched CEOs managed to capture the pay process before SOX, stronger boards are expected to reduce CEO pay for luck and strengthen pay for performance. Using ExecuComp

data, I find that the pay-for-performance link increases after 2002, while pay for luck decreases only in firms with weaker board oversight prior to 2002, that is, in firms more affected by SOX stipulations. In contrast, the pay-for-performance link changes little in firms with independent boards.
\end{abstract}

\begin{abstract}
Abstrakt
Ve své práci zkoumám dopad Sarbanes-Oxleyho zákona z roku 2002 (SOX) na strukturu odměňování manažerů. Zvláště se zabývám zvýšeným dohledem představenstva, který zavedl SOX, a z kterého v tradičních vlastnických modelech vyplývá oslabení vazby odměňování $\mathrm{s}$ výkonem. Jestliže před SOX dokázali pevně usazení manažeři ovládnout proces odměňování, u silnějších rad se očekává snížení odměn manažerů za firemní výkon díky štěstí a posílení odměn za zasloužený výkon. S použitím dat ExecuComp shledávám, že vazba s odměňování za výkon roste po roce 2002, zatímco se odměna za štěstí snižuje pouze u firem se slabším dozorem rady před rokem 2002, tzn. u firem více ovlivněných ustanoveními SOX. Oproti tomu se odměna za výkon málo mění u firem s nezávislými radami.
\end{abstract}

JEL classification: G38; J33; M52

Key Words: Corporate Governance; The Sarbanes-Oxley Act; Incentive Pay

\footnotetext{
* I am grateful to Štěpán Jurajda for invaluable encouragement, guidance and advice. I also thank Jan Bena, Martin Conyon, Randall Filer, Peter Katuščák and Gueorgui Kolev for helpful comments. I thank the Center for Organization Dynamics at the University of Pennsylvania for helping me to access the data during my stay as a visiting scholar. E-mail: teodora.paligorova@cerge-ei.cz

${ }^{+}$CERGE-EI is a joint workplace of the Center for Economic Research and Graduate Education, Charles University, and the Economics Institute of Academy of Sciences of the Czech Republic.

Address: CERGE-EI, P.O. Box 882, Politických vězňu 7, Prague 1, 111 21, Czech Republic
} 


\section{Introduction}

Executive compensation is at the center of a heated corporate governance debate in the U.S. due to its substantial increase in the last two decades. Hall and Liebman (1998) report a $209 \%$ increase of the mean salary in the largest U.S. firms for the period 1980 to 1994. Recently, Bebchuk and Grinstein (2005) use data from 1993 to 2003 and find that CEO pay has increased by $146 \%$ among S\&P 500 firms. The fraud at Enron, WorldCom, Sunbeam, Adelphia, Xerox and Global Crossing in 2001 provided new reasons for discovering what lies behind the astonishing CEO pay bonanza. ${ }^{1}$ Legislative authorities responded quickly to these cases of corporate governance failure with new rules aiming to discipline firms and restore confidence in the security markets.

The major provisions of the Sarbanes-Oxley Act of 2002 (hereafter, SOX) prohibit auditors from performing non-audit services for their audit clients, impose greater criminal penalties for corporate fraud, and require more detailed and timely disclosure of financial information. Further, CEOs and CFOs have to certify financial statements, assess the firm's internal control system, and restrict their own trading activities. In addition, the requirement for managers to return bonuses and stock-trading profits in the case of accounting restatement increases the punishment for $\mathrm{CEO}$ and $\mathrm{CFO}$ misconduct.

Pursuant to the Act, in 2002 both the New York Stock Exchange and NASDAQ introduced rules designed to strengthen the corporate governance of their listed firms. Both exchanges mandated that there be a majority of independent directors on company boards, and a larger role for independent directors in the compensation and nominating committees. The Act also puts emphasis on board monitoring by regulating the role of audit committees. The consequence of the set of regulations is a substantial change in company board structure, supporting effective monitoring. Overall, the Act is viewed as

\footnotetext{
${ }^{1}$ Among many articles in the financial press, Gimein (2002) analyzes the behavior of top executives shortly after the market bubble in the late 1990s. He has found that even when shareholders were, at that time, losing more than $70 \%$ of their holdings, executives became extraordinary wealthy by selling stock and stock options. From 1999 onwards, the magazine concluded that 1,035 companies in the Fortune sample had made $\$ 66$ billion from stock sales, $\$ 23$ billion of which went to 466 insiders in 25 corporations. For a recent discussion on executive pay see a report in The Economist (20/01/2007).
} 
"the most important securities legislation since the original federal securities laws of the 1930s." 2

Due to improved board monitoring, increased responsibilities for executives, and higher costs of misconduct, one would expect the reforms to affect CEO compensation. The purpose of this paper is to empirically examine how the structure of CEO compensation has changed due to the regulations. My analysis is guided by two theoretical perspectives of executive pay, namely by the standard principal-agent theory and the "skimming" hypothesis.

Traditional agency theory (Holmstrom, 1979) suggests that CEO pay is used to reduce a moral hazard problem between the CEO and shareholders by linking pay to firm performance; in practice, executives are offered stock, options, bonuses and long-term incentive plans (LTIPS) to motivate them to maximize shareholder wealth. ${ }^{3}$ Concerned with determining the optimal balance between risk sharing and incentives, this model concludes that pay should not respond to performance beyond CEO control because it might fail to provide incentives (pay-for-performance) and only increase risk. In addition, Hart and Holmstrom (1987) argue that increased board oversight will reduce incentives because direct monitoring reveals $\mathrm{CEO}$ actions and the board can instruct the CEO to act in the owners' best interest, making the provision of financial incentives unnecessary. ${ }^{4}$

Alternatively, the second view, known as rent-extraction or "skimming", refers to the possibility that the CEO gains control over the pay-setting process and, as a result, rewards herself for positive performance shocks beyond her control (pay for luck). Recently the potential of "unjust" CEO rewards has drawn a lot of attention. ${ }^{5}$ Bebchuk and Fried

${ }^{2}$ SEC Chairman William H. Donaldson, September 17, 2003.

${ }^{3}$ See Murphy (1999) and Core et al. (2003) for a survey on the components of CEO pay and the incentives they provide.

${ }^{4}$ Almazan and Suarez (2003), Gibbon and Murphy (1992), and Hartzell (2001) demonstrate theoretically that under agency models different incentive devices act as substitutes.

${ }^{5}$ For example, Lee Raymond, Exxon's CEO, attracted media attention because he retired with $\$ 405$ million compensation, lump-sum pension and current value of stock grants in 2005. Further, Robert Nardelli has received $\$ 210$ million in 2007, while the shares of his company Home Depot fell during his six years in charge. Similarly, Phil Purcell from Morgan Stanley collected $\$ 66$ million severance pay 
(2004) argue that the main reasons for the presence of pay for luck are weak boards, which find it difficult to oppose the CEO who then gains control over the pay-setting process.

Both the principal-agent and the "skimming" perspectives are relevant for an empirical analysis of the consequences of SOX because of its requirement of increased board oversight. The Act provides variation in board monitoring unavailable to previous studies. There is much research exploring the incentives-monitoring relationship empirically; however, such evaluations may be misleading because board monitoring level and CEO pay were often determined by the same person (Hermalin and Weisbach, 2003). ${ }^{6}$ The present research thus extends the existing analyses of monitoring and CEO pay by explicitly using increased board oversight imposed by the lawmakers.

I first document the before/after reform shift in the performance-based components of CEO compensation, which is more closely connected to the monitoring structure and may be better understood from the principal-agent theoretical perspective.

Next, I use the independence of board members as a direct measure of the reform's treatment. Because the reforms call for independence of company boards, firms with many dependent board members at the eve of the Act's passage will be affected the most. Focusing on the specific effect of changing board structure allows for a cleaner identification strategy for the monitoring effect of SOX on executive pay compared to simple before/after comparisons.

In addition, I compare the effect of the reform of CEO pay to the effect on the pay of other executives (except CFOs). The fact that SOX specifically addresses the role of the CEO implies that one can compare within-firm "treatment" and "control" groups, where

in 2004 though the company stock fell $25 \%$ in the last five years. Apparently, CEO pay remains the "acid test in judging whether corporate America is serious about reforming itself" (Warren Buffett, The Economist 20/01/2007).

${ }^{6}$ It would hardly be reasonable to expect that executives sitting on the board would monitor themselves and construct efficient pay schemes. A plausible reason for the lack of strong board oversight is that the nomination process in public U.S. firms allows the CEO to affect the composition of the board; further, board members sit on several boards simultaneously and they have little time and few incentives to negotiate CEO compensation (Fich and Shivdasani, 2006). 
"treatment" includes the CEOs and "control" consists of all other executives but CFOs. This identification strategy is based on the strong assumption of no direct link between the CEO and non-CEO pay but it also allows one to go beyond simple before-after comparisons.

Third, I study how the Act affects the rent-extraction behavior of the CEOs, expecting improved governance to reduce "skimming". Similarly to Bertrand and Mullainathan (2001), I focus on pay for luck - the reward that an executive obtains for company performance driven by industry-wide movements out of her control. I also study separately the effect of positive and negative industry shocks since CEOs are expected to be rewarded for luck during positive shocks and to remain "unpunished" for negative ones (Garvey and Milbourn, 2006).

Using ExecuComp data, I find that the CEO pay-for-performance link increases after 2002 in firms with weaker board oversight prior to 2002, that is, in firms more affected by SOX stipulations. In contrast, the pay-for-performance relationship changes little in firms with independent boards. The pay structure for all other executives remains the same across different board independence levels during the whole analyzed period.

The findings of my pay for luck exploration are consistent with the "skimming" hypothesis. CEO pay shows on average a significant response to luck before the reform, but this response disappears after SOX. Consistent with the improved governance after 2002, CEO pay does not respond either to positive or to negative industry shocks. In contrast, before the reform, positive shocks were highly rewarded, while negative ones were not "punished."

Overall, examining jointly the pay-for-performance and pay for luck parameters of executive compensation, I find that CEO pay can be usefully explained by both, depending on firm governance. After SOX, CEOs in firms with strong board monitoring are rewarded for high company performance as before 2002, while firms with weak boards have strengthened significantly CEO pay-for-performance. While pay for luck is part of the CEO pay in firms with weak boards before the reform, it disappears after the passage of SOX in 2002.

Mine is not the first study of SOX effects on pay for performance. Using a similar 
difference-in-differences approach, Wang (2005) finds that Chief Financial Officer payfor-performance decreases in firms with strong board oversight before the Act and high uncontrollable risk (i.e, risk that cannot be eliminated by maximum auditing), while it increases in firms with weaker board oversight and high controllable risk (i.e., risk that can be eliminated by maximum auditing). My paper contributes to the corporate governance literature by shedding light on the pay of a particularly visible group of executives - Chief Executive Officers - before and after SOX. In addition, my analysis is guided by both pay-for-performance and pay-for-luck perspectives. The latter, known also as pay without performance, gained widespread attention in the recent corporate governance debate (Bebchuk and Fried, 2004). After Bertrand and Mullainathan (2001), and Garvey and Milbourn (2006), who explore the pre-reform period, I focus on the impact of SOX on CEO pay for luck and document that stronger governance, such as that established by SOX, has the potential to reduce pay without performance.

The remainder of this paper is organized as follows: Section 2 explores corporate governance regulations and patterns, Section 3 reviews the related literature, Section 4 presents alternative theoretical views and their empirical implications, Section 5 discusses data and pay patterns, Section 6 offers the research methodology, Section 7 describes the results of pay for performance, and Section 8 proceeds with the results of pay for luck. Concluding remarks are offered in Section 9.

\section{Background}

\subsection{Corporate Governance Regulations in 2002}

The unreliability of corporate managers and board members in the U.S. raised arguments for introducing a regulation that would guarantee confidence in the security markets. The response was the passage of the Sarbanes-Oxley Act in 2002. The corporate governance reforms initiated by the federal government in 2002 are among the most extensive reforms affecting U.S. corporate governance since the establishment of the Securities and Exchange Commission in the 1930s.

The main focus of the Act is the company board structure. SOX mandates that 
the audit committee - the committee that oversees the firms's auditors - be composed of independent directors defined as: "Not receiving, other than for service on the board, any consulting, advisory, or other compensation fee from the issuer, and as not being an affiliated person of the issuer of any of its subsidiaries." The audit committee must have a minimum of three members and consist entirely of independent directors. In addition, each member of the audit committee must be financially literate; one member must be an "audit committee financial expert," or the company must disclose that it does not have such a committee and explain why.

Following the SEC, the NYSE and NASDAQ also adopted new listing requirements. The board of directors of each NYSE- and NASDAQ-listed firm must have a majority of independent directors. Further, the regulations require the independent directors to approve the nomination of directors and CEO compensation.

Timely accurate information for investors is guaranteed by increasing drastically the sanctions for management misconduct. For example, the Act imposes a fourfold increase in the maximum prison term for criminal fraud. In addition, if there is an accounting restatement as a result of misconduct, the Act requires CEOs and CFOs to reimburse any incentive-based compensation or profit from the sale of stock received 12 months after the misreporting (Section 304). Executives are prohibited from selling stock during the pension blackout period and are required to report sales or purchases of company stock within two days, rather than the previous - ten days after the transaction (Section 306). According to the NYSE regulations, shareholders have to approve all equity-based compensation programs.

The public reaction to the passage of the Act was controversial. Its fast passage was viewed as a political product (Hilzenrath et al., 2002) that was negatively accepted by the business community because of the high implementation cost. Executives argue that the Act will divert their attention from doing business to complying. A survey by Financial Executive International finds that the average first-year cost estimate is almost $\$ 3$ million for roughly 26,000 hours of internal work and 5,000 hours of external work, plus additional audit fees of $\$ 823,200$ or $53 \%$ more in comparison with the pre-SOX period.

Holmstrom and Kaplan (2003) reason that the Act provisions increase the risk for 
CEOs and CFOs for selling a large amount of stock options because of the possibility to be accused of "misconduct". This will make the executives more reluctant to cash in their equity holding and henceforth their portfolios will be less liquid. The authors suppose that this might have a positive effect on firm value, since managers will shift their attention from short- to long-term stock prices.

Further, it is believed that SOX might affect the labor market for directors. Because of the requirement of "independence," the demand for those directors might exceed their supply due to the lack of such a type of managers. Previous work suggests that the supply of managers is inelastic, therefore shocks to aggregate demand, like the increased need for "independent" directors, raises the marginal value of their labor service (Himmelberg and Hubbard, 2000).

\subsection{Corporate Governance Patterns}

One mechanism of corporate governance operates through company board structure and particularly, its share of independent directors, assuming that the higher the number of independent directors, the better the corporate governance is. Table 1, using IRRC data (see Section 5 ) examines recent corporate governance patterns separately for 1998, 2001, 2002 and 2004. Specifically, the share of employee and linked directors has decreased over time, while the share of independent directors has risen. ${ }^{7}$ The increasing number of independent board members can be viewed as a positive change towards better corporate governance. It is not surprising to observe this trend because the Sarbanes-Oxley Act of 2002 requires a 100\% independent audit committee, and the NYSE regulation demands an independent nominating and compensation committee. ${ }^{8}$

\footnotetext{
${ }^{7}$ According to the Investor Responsibility Research Center (IRRC), a director who is linked to the company through certain relationships and whose views may be affected because of such links is classified as affiliated (linked). For more details see www.irrc.com/resources/glossary.htm.

${ }^{8}$ The share of independent directors is increasing over the whole period from 1998 to 2004 . In order to distinguish the trend effect from the potential effect of SOX, I estimate a regression where board independence is a left-hand side variable and a linear trend and a dummy for the passage of the Act are right-hand side variables. The results show that the percent of independent directors increases significantly after 2002, even after accounting for the trend.
} 
Further, the table reports that boards met more often in 2004 than in 1998, presumably indicating greater effort. In addition, the board size decreased on average, which is associated with better governance, from 9.62 in 1998 to 9.37 in 2004 . At the same time the annual fees for attending board meetings has risen by $72 \%$ on average. A recent study finds that "busy" boards, having directors who hold more than three directorships, are associated with weak corporate governance, lower market-to-book ratios and profitability (Fich and Shivdasani, 2006). Fortunately, we observe that fewer directors choose to serve on more than three boards after SOX - 20\% in 1998 and 15\% in 2004-presumably resulting in higher board efficiency.

The main corporate governance tendencies for the period 1998-2004 measured with board structure show that boards became more independent, smaller, met more often and were less "busy," all of which indicates an improved corporate governance environment after 2002. ${ }^{9}$ These simple descriptive findings allow one to conclude that the Act indeed changed corporate governance, which might cause changes in executive pay structure.

\section{Empirical Literature}

My analysis builds on several strands of research. First, in a broad sense, I extend the literature on corporate governance, which examines how the board of directors, institutional shareholders, large creditors and the market for corporate control affect executive behavior and organizational performance. Second, I complement the small amount of literature on the effect of regulations on executive compensations; particularly, I extend the literature on the Sarbanes-Oxley Act of 2002. In this section, I briefly discuss each of the related areas of research.

\subsection{Managerial Pay and Corporate Governance}

The vast majority of existing studies links CEO pay to CEO power. Different measures of CEO power, such as whether the CEO is involved in the nomination process of new direc-

\footnotetext{
${ }^{9}$ Yermack (1996) finds an inverse correlation between board size and firm value. Companies with small boards also exhibit more favorable values of financial ratios than firms with large boards.
} 
tors, whether the CEO has interlocking relations, ${ }^{10}$ the percentage of affiliated directors on the board, whether the CEO is also the chair of the board and whether the number of directors on the company board are employed. Hallock (1997) finds that boards with interlocking directors give a higher wage to the CEO. Similarly, Core et al. (1999) show that the wage of the CEO is positively correlated with the presence of interlocking relations, the $\mathrm{CEO}$ in the role of chair, and the percentage of affiliated directors. Grinstein and Hribar (2004) discover that a powerful CEO, who is also a chaitman manages to extract higher bonuses. In contrast, Daily et al. (1998) fails to detect a connection between compensation committee independence and CEO compensation. Institutional ownership concentration is positively related to the pay-for-performance sensitivity of executive compensation and negatively related to the level of compensation, which suggests that institutions might serve as monitors that mitigate the agency problem (Hartzell and Starks, 2002).

Usually the relation between corporate governance mechanisms and CEO pay is endogenous (Hermalin and Weisbach, 2003, Becht et al., 2002) because CEO pay can be simultaneously a result and part of the governance mechanisms. One approach to address this issue is to use ex-post performance metrics to infer causality. Core et al. (1999) investigate the consequences of excessive CEO compensation in firms with weaker governance and find a negative relation to future performance. The other approach is to generate an exogenous variation in the governance mechanisms, usually through changes in new legislation, and analyze before/after changes in the CEO compensation. In this paper, I rely on the second approach and use the Sarbanes-Oxley Act of 2002 as a source of exogenous board monitoring to identify shifts in executive pay.

\subsection{Managerial Pay and the Sarbanes-Oxley Act of 2002}

Before the passage of the Sarbanes-Oxley Act, few studies focus on the impact of various law regulations on executive pay. Hubbard and Palia (1995) find that CEOs in the banking industry earn more after banking deregulation in the U.S. in the 1980s and

\footnotetext{
${ }^{10} \mathrm{~A}$ situation where an executive in one company sits on a board of another company and the executive of the second company sits on the board of the first company.
} 
exhibit a stronger pay-for-performance link. Bertrand and Mullainthan (1999) consider state anti-takeover legislation. They suppose that a reduction in takeover threats should raise pay because the entrenched CEOs can "skim" more easily whatever pay they can. In other words, the lack of takeover threat allows entrenched CEOs to increase their rents at the expense of the shareholders. The authors find that large shareholders, who are associated with strong governance, help in limiting the rise in mean CEO pay after the passage of the law and also increase their pay-for-performance sensitivity.

So far there are only a few studies that directly explore the impact of the SarbanesOxley Act using ExecuComp data. My paper closely resembles the approach of Wang (2005), who contrasts the effect of the Act on CFO pay in firms with strong and weak board oversight before the Act and with controllable and uncontrollable risk of material misstatement of an unaudited financial report in the absence of internal control procedures. According to Wang (2005) two factors are expected to affect CFO pay, the first is increased risk, and the second is increased monitoring. Wang argues that firms with strong boards will be affected mainly by the rise in risk. Thus, these firms will respond to the increased risk with reduced incentive pay according to standard agency theory. The firms with weak boards, however, will be affected by both a rise in risk and improved monitoring. The direction of the change in pay is unclear since it depends on the proportion of uncontrollable risk, managerial risk aversion and the cost of effort.

The findings of Wang (2005) are that CFO's incentive pay is reduced after SOX in firms with strong boards prior to the Act and with a high proportion of uncontrollable risk; further, firms with weak boards before the Act and low uncontrollable risk seem to increase CFO incentive compensation after the reform.

Cohen et al. (2004) study the change in the structure of executive compensation after the passage of the Sarbanes-Oxley Act in 2002. The hypothesis is that firms will respond to the increased liabilities by lowering the incentive component of managerial pay and by increasing the fixed one that insures against risk beyond the CEO's control. The results based on the ExecuComp data confirm an increase of fixed salary and a decrease in incentive-based compensation of CEOs after the Act. The shift from more risk to less risky pay is interpreted as a form of insurance against the imposed liability after SOX. 
Another finding of the paper is that CEOs participate less in risky activities after SOX, which might affect negatively shareholder's return because of forgone profitable projects.

Unlike Cohen et al. (2004), I introduce a cleaner identification strategy for the effect of the Act by going beyond a before/after comparison. Unlike Wang (2005), I focus on CEOs. She claims that CFOs are a more targeted group by the Act because they are in charge of firms' financial reporting. However, I consider it equally important to focus on CEO pay, because their responsibilities are changed by the Act. When examining pay in the context of agency theory, which relies on a direct link between agents' pay and their actions, it would be reasonable to assume that CEOs' actions influence firm performance to a greater extent than CFOs' actions.

\section{Theoretical Perspectives and Empirical Implica- tions}

\subsection{Incentives}

Two major theoretical approaches explain the role and composition of executive pay. First, principal-agency theory assumes that managers are likely to place personal goals ahead of corporate goals, resulting in a conflict of interest between shareholders and management. Jensen and Meckling (1976) demonstrate that investors in publicly traded corporations incur (agency) costs of monitoring managerial performance. In general, agency costs arise whenever there is an information asymmetry between a corporation and outsiders because insiders (managers) know more about the company and its future prospects than outsiders (investors) do. One way to limit agency cost is to offer such a pay package to managers that they would have incentives to act in the best interest of the shareholders. Usually managerial compensation is tied to the financial performance of the company by issuing stock options related to the firm's stock price, which is supposed to encourage the manager to maximize the value of shares. Thus, a regular managerial contract provides incentives (stock option, long-term incentive plans, stock, restricted stock) that give a manager reasons to take a risky project in favor of shareholders' and 
insurance that guards the managers against events out of their control.

There are two approaches for estimating the relation between CEO wealth and shareholder wealth. According to the first one, CEO wealth is directly tied to shareholder wealth through holdings of stock, restricted stock and stock options; the second approach, which I employ in my analysis, assumes that CEO wealth is indirectly related to shareholder wealth through accounting-based bonuses and through year-to-year changes in salary levels, bonuses, options and restricted stock. These year-to-year performancerelated changes in total compensation are typically modeled as:

$$
\log \left(\text { Pay }_{i t}\right)=\beta \text { Return }_{i t}+\delta X_{i t}+\zeta t+\eta_{i}+\varepsilon_{i t},
$$

where $\mathrm{i}$ indexes firms, $\mathrm{t}$ indexes time and $\beta$ is a CEO pay-for-performance link. Return is a vector of contemporaneous and lagged performance measures, $X$ is a set of individual and firm specific characteristics, ${ }^{11} \zeta$ is time trend estimate and $\eta_{i}$ is a CEO or firm-specific effect.

According to agency theory, pay for performance is but one among many devices for realigning the interests of managers to those of shareholders. Bertrand and Mullainathan (1998) see the threat of a takeover to be another incentive device that motivates CEOs to perform better. In my study, I use the monitoring role of independent directors as an incentive device that potentially can motivate managers to act in the interests of their owners. Different incentive devices work as substitutes. ${ }^{12}$ The passage of SOX

\footnotetext{
${ }^{11}$ Usually in the literature, CEO age, tenure, firm size and book-to-market ratio are controlled for. Particularly in my pay regression, I account for the effect of firm performance before 2002, the passage of the Act in 2002, firm performance after 2002, time trend squared and firm size; moreover, the results of pay-for-performance prove to be insensitive to the inclusion of age, tenure, book-to-market ratio and lagged performance.

${ }^{12}$ Monitoring not only has benefits in terms of reducing the agency costs, but also carries opportunity costs in terms of aggravating the agency problem. For example, entrenched managers might appoint their friends to the company board and thus capture the pay setting process. It can be shown analytically that monitoring reduces the variance of the managers' pay. Monitoring redistributes risk from the managers to the owners. The purpose of monitoring is to reduce the degree of information asymmetry between the managers and owners and thereby to enable owners to tailor the managers' rewards more closely to their actions rather than to profits. Hence, the result of increased monitoring should be to reduce pay
} 
demands stronger monitoring through majority independent directors, which according to the principal-agent theory might lead to a lower level of pay for performance because the corporate board can now instruct the manager to take actions leading to the maximum shareholder value. In such a way, pay for performance turns into a useless incentive device.

In my analysis I distinguish between two types of firms. The first includes firms with independent board structure prior to the reform, while the second includes firms with dependent board structures, i.e., those that had to change their boards because of SOX. Guided by agency theory that monitoring and incentives are substitutable, my hypothesis is that the first group of firms will not exhibit a pay-for-performance shift because it will not change its monitoring mechanism; however, the second group will be obliged to appoint independent directors, which presumably leads to better monitoring. In this case pay-for-performance will be substituted by stronger board supervision.

\section{2 "Skimming" Hypothesis}

CEO pay-for-performance can be viewed as a mechanism to solve the agency problem. Nevertheless, it might happen that CEOs have managed to capture the pay process so that they set their own pay by extracting rents, which can be constrained by the availability of cash (free cash flow hypothesis), by the efficiency of monitoring, both by the board and/or institutional shareholders, by the fear of drawing shareholders' attention or by stricter legal regulations such as the Sarbanes-Oxley Act.

Bebchuk and Fried (2004) argue that because options contracts lack explicit relative performance valuation, executives receive windfall gains as market value increases. Inspired by this view, I explore the impact of luck on CEO pay, where luck is an event that has little to do with CEO activities. In general, an optimal CEO contract should not depend on luck, because it does not provide incentives for enhancing shareholder value. I define luck as the company performance driven by industry-wide returns. To

for performance relative to the situation without monitoring. However, monitoring will happen only if the cost of doing so is offset by the additional pay off of economizing incentives. Monitoring will not be undertaken if marginal costs are too high or if firm risk is too low. 
estimate the sensitivity of pay to luck, I employ a two-stage procedure. In the first stage, the changes in firm performance due to luck, measured with industry-wide return, are isolated; in the second stage, the sensitivity of pay to these predicted changes in firm performance are estimated. Similarly to Bertrand and Mullainathan (2001), I estimate the following equations:

$$
\begin{aligned}
& \text { Return }_{i t}=\beta_{1} \text { IndustryReturn }_{j i t}+\delta_{1 X} X_{i t}+\zeta_{1} t+\eta_{1 i}+\varepsilon_{1 i t} \\
& \log \left(\text { Pay }_{i t}\right)=\beta_{2} \text { Return }_{j i t}+\delta_{2 X} X_{i t}+\gamma \widehat{\varepsilon_{1 i t}}+\zeta_{2} t+\eta_{2 i}+\varepsilon_{2 i t} .
\end{aligned}
$$

Industry Return is the weighted industry return on assets in year $t$ in the 2-digit SIC industry $j$, where firm $i$ itself is excluded from the mean calculation. Here $\beta_{2}$ is the estimated component of firm performance common to the industry group and not attributable to $\mathrm{CEO}$ actions or $\mathrm{CEO}$ quality, and $\widehat{\varepsilon_{1 i t}}$ is the estimated residual from the first equation. The coefficient of firm-specific performance, $\gamma$, could reflect both CEO skill and/or unobservables unrelated to industry performance. Supposing that the CEO is not compensated for luck, we would expect a lack of sensitivity of industry-induced return to CEO pay. A recent study by Garvey and Milbourn (2006) raises an important point that positive sensitivity of pay to industry return might be compensation for bearing systematic risk but not necessarily pay for luck. This argument assumes that managerial pay is linked both to good and bad industry fortune. However, if executives have overcome the pay setting process, it is expected their pay to be sensitive to the industry performance when the industry (benchmark) is up but not when it is down. I explore this hypothesis in Section 8.

The Sarbanes-Oxley Act is a mechanism that aims at strengthening corporate governance, which potentially might restrict lucky pay. A previous study shows that in the presence of large shareholders, which is associated with strong governance, CEO pay responds less to luck (Bertrand and Mullainathan, 2001). In this paper, I study how SOX affects CEO pay for luck in firms with dependent boards, assumed to be poorly governed and in firms with independent boards, considered to be well-governed. Supposing that the skimming view can explain executive pay, we might expect that after the reform, dependent boards will strengthen company monitoring and limit the possibility for executives to control the pay-setting process, resulting in less pay for luck. In 
contrast, well-governed firms, are not expected to change their pay structure after SOX because pay for luck has not been part of their compensation package before the reform was implemented.

\section{$5 \quad$ Sample and Descriptive Statistics}

\subsection{Sample}

The Standard and Poor's ExecuComp database provides information about the five highest-paid executives available in proxy statements. Disclosure rules for U.S. executives require details on salary, annual bonuses, option holdings, equity and option grants, age, and tenure. The database covers firms from the S\&P 500, the S\&P Mid-Cap 400, the S\&P Small-Cap 600 and other supplemental S\&P indices. ${ }^{13}$ The IRRC data is of annual frequency and covers the directors of the S\&P 500, S\&P 400 mid-cap and S\&P 600 small-cap firms for the period 1996 to 2004. The data provides details on the structure and practices of the boards of directors, historical information for each director, such as the committees they belong to, board affiliation, shares held and total voting power.

The ExecuComp sample contains 2,350 firms or 14,592 firm-years for the period 19982005 (See Table 2). Officers named as Chief Executive Officers (CEOs) are defined by the CEOANN field for each year. ${ }^{14}$ In 1998, around $10 \%$ of the firms in the ExecuComp data did not report their CEOs, while in 2005-only 1\%. Before excluding these firms from the analysis, I make a sample selectivity analysis on the relation between the incidence of not reporting CEOs and firm observable characteristics. The results from a logit regression show that none of the estimated set of parameters is statistically significant, which insures against biases from systematic non- reporting.

The IRRC data covers 2,906 firms or 11,514 firm-years for the period 1998 to 2004 . The initial sample, obtained after matching both data sets over the period 1998-2005,

\footnotetext{
${ }^{13}$ Since the sample contains both large- and small-cap firms, ex-post survivorship bias is less likely.

${ }^{14}$ Chief Operating Officer (COO) and Chief Financial Officer (CFO) are retrieved from the field TITLEANN. The group of COOs is considerably smaller in comparison to CEOs and CFOs. It is possible that COOs are not ranked among the top highest-paid executives, nor are they reported in the data.
} 
consists of 1,722 executives named as CEOs and 10,812 firm-years. ${ }^{15}$ Firm-level data are taken from COMPUSTAT industrial annual database. The industry affiliation is based on the SIC-code classification. ${ }^{16}$ The three largest industry groups in the sample are coming from Commercial Banks (SIC 6020, 4.5\% of the sample), Prepackaged Software (SIC 7372, 4.19\% of the sample) and Crude Petroleum and Gas (SIC 1311, 2\% of the sample). Further, after eliminating firms with missing data on either total pay or return, the analysis-ready sample consists of around 1,650 firms and 10,000 CEO-firm-years.

The data have strengths and weaknesses. Among the strengths is detailed unified information on the top five highest-paid executives over a 14-year period; the data set is large and contains information for 1,500 firms that cover about $80 \%$ of the U.S. market capitalization. As for the weaknesses, there are 365 firms present in ExecuComp but not in IRRC. ${ }^{17}$ A sample selectivity analysis explores whether the non-matched firms, which are the firms available in the ExecuComp sample but missing in the IRRC data for the period 1998-2002, are randomly distributed across firms with different characteristics. The results show that small-cap firms are more likely to be missing in comparison to the large-cap and mid-cap firms.

\subsection{Executive Pay Patterns}

Table 3 provides summary statistics for the average percentage change of various CEO pay components from 1998-2001 to 2002-2005. ${ }^{18}$ Several notable tendencies can be observed. First, based on the sample average, the level of salary and bonus increases by 26 percent after 2002. The rise is pronounced the most firms operating in the service sector and it is smoothly spread among firms with different market capitalization. CEOs in firms

\footnotetext{
${ }^{15}$ Because I define company board independence before 2002 only, in the regression analysis I rely on a successful match between IRRC and ExecuComp only for the period 1998-2002. If a firm is present at least two years in this period and stays in the sample after 2002, it belongs to my analysis-sample.

${ }^{16} \mathrm{See} \mathrm{http://listsareus.com/business-sic-codes-q.htm} \mathrm{for} \mathrm{details.}$

${ }^{17}$ I use the October 2006 version of IRRC, which does not cover 2005.

${ }^{18}$ The statistics come from the estimation of pool-sample regressions where a SOX dummy coefficient captures the percentage differences presented in Table 3.
} 
with dependent boards before SOX make on average $28 \%$ higher salary and bonus after the reform, while CEOs in firms with independent boards make $25 \%$ more, though the difference between the types of firms is not significant. Second, total pay, including salary, bonus, benefits, total value of restricted stock granted, total value of stock options granted, long-term incentive payouts and all other pay, increases on average by $16 \%$ after SOX. The results show that firms from mining and manufacturing have the highest increase compared to other sectors, while CEOs in the finance and insurance sectors do not earn more compared to the pre-SOX period. Looking separately at independent and dependent board firms, the increase in the former group is smaller than in the latter. Third, shifting attention to the option values, no change is observed; however, there is large variation across industry sectors. Option value in mining and manufacturing firms has increased after 2002, while that in finance and insurance sectors has dropped by $30 \%$. Since the value of the stock option depends on various characteristics, ${ }^{19}$ to shed more light on the reasons behind the fall of the options value in this sector before and after 2002, I explore the change of the number of options granted as a portion of total shares outstanding. It appears that finance and insurance firms grant significantly less options after 2002, which explains the decrease in their total value.

Figure 1 demonstrates the average pay level across years. As expected, the highest pay is in 2000 and 2001 when a series of corporate scandals bursted. As for CEO salary and bonus, which constitute around $30 \%$ of the whole pay package, the increase is gradual over time. Increases in option value contribute to the total pay rise up to 2003; however, afterwards, even though the value of options granted drops, the total pay increases. Apparently, other pay components such as restricted stock have become preferred to stock options.

Looking at firm-level patterns, Table A1 (in the Appendix) shows that both return

\footnotetext{
${ }^{19}$ The most widely used method for valuing options is the Black-Scholes formula adjusted for continually paid dividends. The value of European call option paying dividends is: OptionValue = $P e^{-\ln (1+d) T} N(z)-X e^{-\ln (1+r)} N(z-\sigma \sqrt{T})$, where $\mathrm{P}$ is the grant-date stock price, $\mathrm{X}$ is the exercise price, $\mathrm{T}$ is the time remaining until expiration, $\mathrm{d}$ is the annualized dividend yield, $\sigma$ is the stockprice volatility, $\mathrm{r}$ is the risk-free discount rate, $\mathrm{N}($.$) is the cumulative distribution function, and$ $z=\left(\ln (P / X)+\left[\ln (1+r)-\ln (1+d)+\sigma^{2} / 2\right] T\right) /(\sigma \sqrt{T})$.
} 
on assets and the stock return mark their lowest value in 2001 and 2002-the year of the reform passage. Average sales increased from $\$ 3.7$ billion in 1998 to $\$ 6.5$ billion in 2005. A comparison of firm characteristics between dependent and independent board firms indicates that there is no statistically significant difference between both groups.

Overall, the CEO pay pattern reveals an increase in salary and bonus after SOX, and a remarkable increase of restricted stock. These descriptive findings are hard to interpret, though. There could be factors other than SOX after 2002 that influenced the change. The rest of this study asks to what extent the observed mean pay patterns can be explained by differences in firm characteristics before and after SOX.

\section{Research Methodology}

I use the fall of Enron in 2001 as a motivating event for the corporate governance reforms in 2002. ${ }^{20}$ The pre-reform period of analysis is from 1998 to 2001 and the post-reform from 2003 to 2005. Year 2002 is dropped as it is the reforms were enacted.

I employ the main requirement of the Act for the majority of independent directors on compensation, nomination and audit committees to define how a certain aspect of SOX, namely improved board oversight, affects CEO pay. For this purpose, I analyze separately firms with stronger board oversight and firms with weaker board oversight as of before the reform. I consider firms with weak board oversight to be the "treated" group as opposed to the "control group," that is firms with strong board oversight.

Using legislation that mandates board independence helps to better identify the monitoring effect on pay for performance. Previous studies using cross-sectional data to examine board monitoring and compensation pay rely on a potentially endogenous source of variation. The observed variation in board oversight was limited before the reform, even where studies could benefit from the advantages of panel data, because the CEO herself would influence the pay process either personally or through the network of friends

\footnotetext{
${ }^{20}$ The implementation of the Act started soon after its passage. The final rule was agreed upon on July 24 (VandeHei et al., 2002), passed in Congress on July 25, and signed into law on July 30. August 14, 2002 was the first deadline for CEOs and CFOs of the 947 largest firms to certify the truthfulness of their financial reports.
} 
sitting on the board. Using the Act as a "surprising" event that causes a forceful change in the board structure suggests a better identification of the relationship, though the extent of board change depends on the composition of the board before the reform.

Little change in the CEO pay-for-performance sensitivity for the "control" group is expected because these firms have already met the requirements of SOX for board independence. The "treatment" group, however, is expected to experience a change in pay for performance because of a stronger shift in board independence.

I use two measures for board independence. First, I construct ten portfolios according to firms' sales and define the median percent of independent directors in each portfolio. ${ }^{21}$ Then, for each portfolio I classify a firm as belonging to the independent-board subsample if its percent of independent directors is higher than the median percent of independent directors in the relevant portfolio. Similarly, the sample of dependent board firms prior to the reform are those with a lower percent of independent directors than the portfolio median. This measure accounts for the positive impact of firm size on independence documented first by Bebchuk et al. (2003) and confirmed in the present sample. Second, I consider an alternative proxy that does not depend on firm size, but only on the firm's majority of independent directors (more than $50 \%$ of all board members).

Table 4 reports how board structure is alter after SOX and confirms the actual reform's treatment. Regardless of the way an independent board is defined, we observe that the reforms seem to affect firms with dependent boards more than firms with independent boards. For example, the share of independent audit committee members increases by $22 \%$ for the median-portfolio-based approach and $24 \%$ for the majority-rule-based one. Overall, the percentage increase of the share of different types of independent directors is significantly higher (at the 1\% level) in firms with dependent boards than in firms with independent boards before SOX, which provides grounds to use board structure as a proxy for the changed monitoring due to SOX.

The Act introduces significant changes in the responsibilities of certain executives, the CEOs (and CFOs), which are employed to study within-firm pay differences between

\footnotetext{
${ }^{21}$ I employ the IRRC definition of an independent director. This is a director not affiliated with the company. For details see www.irrc.com.
} 
CEOs and non-CEOs. Thus in addition to the before/after change of pay, and the pay change between CEOs in independent and dependent boards, I add to the analysis the change between CEOs and non-CEOs pay. Including non-CEOs, who are not affected by the Act, allows controlling for various macroeconomic and systematic shocks on the managerial labor market, thus ensuring even a cleaner identification of the effect of SOX.

\section{$7 \quad$ Pay for Performance}

In this section, I first examine the change in pay-for-performance sensitivities before and after SOX for all firms. Next, I study the change in pay-for-performance sensitivities separately for firms with dependent and independent board structures. Finally, in addition to comparing the before/after differences across independent/dependent firms, I analyze the difference between $\mathrm{CEO}$ and non-CEO pay.

Following the previous literature, I assume that CEO pay, measured by either salary and bonus or total pay (summation of salary, bonus, options granted to managers, LTISs, the value of restricted stock grants and other pay), is a function of accounting return measures on assets (ROA) and firm sales. ${ }^{22}$ Changes in the value of the CEO's existing shares and options are ignored. Whether the consequence of this exclusion is an underestimation of the managerial incentives depends upon the managers' activities regarding their personal portfolios. ${ }^{23}$ Given the difficulty of controlling for managers' activities, using current compensation has the advantage of measuring only compensation components, over which the board of directors has direct control. Moreover, the focus of my analysis is on the potential influence of SOX on executive pay, rather than on the optimal managerial pay dynamics. Since the major channel of SOX regulation comes through the board's decisions, presumably affected by strengthened independence, the current com-

\footnotetext{
${ }^{22}$ Studies using accounting return measures include Leonard (1990) and Sloan (1993). In untabulated results I verify that all the inferences reported in this section hold when I consider stock return as a measure of firm performance.

${ }^{23}$ Ofek and Yermack (2000) report evidence that managers alter their portfolios in response to the composition of their pay packages. Similarly, managers counteract the effects of existing holdings through hedging transactions.
} 
pensation measures are more appropriate for my tests. In addition, I study the impact of SOX on pay for luck (See Section 8), which does not vary with fluctuations in already granted pay. I assume that the Act has limited control through board oversight over the amount of pay that CEOs choose to retain in their portfolios. The use of current compensation is further justified by Core and Guay (1999) who conclude that firms use flow of equity incentives to reward past performance and re-optimize incentives for future performance.

A well-documented feature of the ExecuComp data is the right skewness of pay, implying that only a small fraction of executives earn extremely high pay. To reduce the effect of outliers, I drop observation falling outside of the 1-to-99 percentile range of pay. Return on assets is the net income before extraordinary items and discounted operations divided by total assets. Sales are measured by net annual sales as reported by the company. To control for the upward trend of CEO pay during the analyzed period from 1995 to 2005, I include a quadratic time trend in years. Most of the studies on managerial pay use the fixed effect model to control for unobserved heterogeneity among firms and/or executives. ${ }^{24}$ The difference-in-differences approach is employed to estimate the impact of the Act. ${ }^{25}$ The advantage of this methodology is that it measures the effect of the Act by comparing pay-for-performance sensitivities. However, it is well known that the difference-in-differences estimator is based on strong identification assumptions. In particular, it is required that in the absence of treatment, the average outcomes for the treated and control group would follow parallel paths over time. I perform tests for the equality of mean pay between CEOs in independent (control) and dependent (treated) board firms. The results suggest that the mean pay in firms with independent boards is not statistically different than the mean pay in firms with dependent boards, except for in 2003 and 2005, when the difference is statistically significant at the $10 \%$

\footnotetext{
${ }^{24}$ Murphy (1985) shows that controlling for firm fixed effects is important in the managerial pay literature.

${ }^{25}$ See Heckman and Hotz (1989) for an exposition of difference-in-differences, and Bertrand and Mullainathan (1998) for an application of this methodology to analyze the effect of legal regulations on CEO pay.
} 
level. Similarly I examine the ROA path over time and find that only in 1998 the mean ROA differs between the group of independent and dependent board firms. Overall, the assumption of a similar pattern of compensation for the treated and control group seems to be supported by the data.

Table 5 presents the estimated CEO pay specifications separately for the full sample, for firms with dependent and independent boards. The pay-for-performance elasticities for the full sample (column 1) before the reform, measured with the estimates of ROA, suggest that a one percentage point increase in return on assets leads to a $1.3 \%$ percent rise in pay. Although the result is comparable with previous research (See Murphy, 1999; Wang, 2005), the discussions in this paper focus on changes in sensitivity while ignoring the debate on the magnitude of estimates. The post-reform pay-for-performance coefficient increases significantly by almost 25 percentage points, resulting in an increase of total pay of almost 1.6 percent. ${ }^{26}$

Next, I explore whether firms exposed to a stronger reform treatment, namely, firms with dependent boards, react differently from those firms that were less affected by the Act, i.e., the independent board firms. If there was a common shock correlated with the passage of the Act that affects all firms, the above approach will not identify correctly the impact of SOX. To address this issue, I estimate separately pay-performance sensitivities for independent and dependent board firms. The latter group of firms do not change their pay-performance policy after SOX (column 2, Table 5); however, dependent board firms increase the link between firm performance and CEO pay by almost $50 \%$. The effect of the reform is actually the difference between pay-for-performance postreform changes between the "treated" and "control" group, that is $0.63(\mathrm{p}<0.12)$. The statistically significant difference-in-differences estimate provides some evidence that the rise in incentives is valid only for the "treated" group of firms. These findings are similar to those of Wang (2005) who examines CFOs who are affected by SOX similarly as CEOs.

Further, the results in Table 5 are preserved when analyzing CEO salary and bonusthe reform leads to a rise in pay-for-performances only in dependent board firms. Mod-

\footnotetext{
${ }^{26}$ The statistical inference accounts for the group-level variation in ROA by clustering residuals at the firm level.
} 
eling the time trend with less restrictive time dummies does not change the results. In addition, the results are not sensitive to including additional control variables usually considered in the executive pay literature. Particularly, I control for the variance of stock return calculated over 60 months as a measure of the noise of firm performance, ${ }^{27}$ lagged return, ${ }^{28}$ book-to-market ratio, CEO age and CEO tenure.

Table 6 presents the results for the sample of non-CEOs, which includes all reported executives except CFOs. ${ }^{29}$ Since the Act does not address all executives, but CEOs and CFOs, the analysis can be further refined by forming an additional within-firm "treated" group - CEOs - and a "control group" - non-CEO executives. Comparing payfor-performance sensitivities between CEOs and non-CEOs will difference out the impact of common shocks on the managerial labor market. The same regression specifications for CEOs are estimated. ${ }^{30}$ Basically, the results show that the non CEOs pay for performance estimates do not change for independent and dependent boards after the passage of the Act. This evidence further provides support that the change in pay for performance in the treated group can be attributed to the reform, because the pay for performance of the control group remains the same as before the reform. ${ }^{31}$

Figure 2 combines the estimated pay-for-performance coefficients with their corresponding 95\% confidence intervals for CEOs and non-CEOs separately, before and after

\footnotetext{
${ }^{27}$ Aggarwal and Samwick (1999a) argue that ignoring the volatilities and their interactions with firm performance understates the pay-performance link. The variance captures both size and risk effects.

${ }^{28}$ See Core (2002) for a discussion of the roles of different performance measures on CEO pay. Because past performance may have an influence on current compensation (Jensen and Murphy (1990), lagged return has to be included as a regressor. The total sensitivity is the sum of the current and lagged return coefficients. The before/after effect of SOX on CEO pay is similar to the specification without lagged performance.

${ }^{29}$ Chief Financial Officers are omitted from the analysis since they are also affected by the Act. For more details on the effect of SOX on CFO pay, see Wang (2005).

${ }^{30}$ Since there are more than one executive in a firm, I also examine executive fixed effect to account for managerial talent differences. Similar estimates are obtained.

${ }^{31}$ I estimate a specification where CEO and non-CEO pay are assumed to share the same time trend and pay for firm size elasticities. The results are similar to the results in Table 5 and 6 .
} 
SOX, for independent and dependent boards. It is clear from the figure that non-CEO pay for performance is stable before/after SOX and between dependent/independent board firms unlike CEO pay for performance.

I assess the sensitivity of the results to the measure of board independence. Alternatively according to the definition in Table 5 and 6 , based on decile sales portfolios, I re-estimate CEO-total pay regressions, dividing the firms into four groups based on board independence quartiles and into two groups based on the majority of independent directors.Both measures are calculated prior to the passage of SOX in 2002, in accordance with the definition in Table 5 and 6 . The results are presented in Table A2 in the Appendix. While the estimated effect of SOX on pay-for-performance elasticities is significant in the lower two quartiles, where the group of firms with dependent boards is, the sensitivities remain the same after the passage of SOX for the group of firms in the upper quartiles. The results are similar when the sample is split into two groups depending on the majority of independent directors. A significant positive change is detected only for the firms with less than $50 \%$ of independent directors. In sum, regardless of board independence, the definition of CEO pay for performance increases after SOX in firms with dependent boards defined prior to the reform; however, no such change is detected for independent board firms.

A question arises as to whether these findings are consistent with the standard agency models. Bertrand and Mullainathan (1998) study the impact of takeover legislation on executive pay and find that pay for performance increases after the passage of antitakeover legislation in the 1980s. They explain this evidence with the substitution effect of alternative incentive mechanisms inferred from the agency theory - if a reduction in the takeover threat is present, then pay for performance will rise to compensate for the weakened threat of takeover. Guided by the same theory, all else equal, I expect CEO pay for performance to decrease in firms with dependent boards after SOX because they will respond to the increased board oversight with lower incentives, i.e., lower pay for performance.

The present results, however, seem to be puzzling in regards to this view. Pay-forperformance and increased monitoring through independent directors after SOX, behave 
as complimentary mechanisms rather than as substitutes that reduce the degree of asymmetry between principal and agent. Potential explanation for the limited evidence in support of the standard agency theory can be found in the optimal contracting perspective. Improved board oversight will happen only if the cost of doing so is offset by the additional payoff of not increasing pay for performance. Stated differently, after SOX the marginal benefit of implementing contracts characterized by increased pay for performance and increased board monitoring has to be greater or equal to their marginal costs. Demsetz and Lehn (1985), for example, find evidence of increasing monitoring costs in more risky and uncertain environments, thus, instead of enduring greater monitoring costs to oversee CEO actions, shareholders use equity incentives to motivate managers. It might be too costly for boards in the process of restructuring to meet the requirements of SOX and to exercise active monitoring. The evidence rather suggests that they choose to strengthen an alternative incentive device, namely pay for performance.

Moreover, the executive contract is not just a one-dimensional arrangement including pay for performance and monitoring (Kole, 1997). Other factors might affect these contracts. Garvey and Milbourn (2006) are concerned that the increase of firm performance sensitivity to CEO pay might be in part a windfall. Pay might be sensitive to exogenous forces (luck) linked to firm performance but irrelevant to CEO actions. Bertrand and Mullainathan (2001) refer to the phenomenon of pay for luck as managerial "skimming," according to which managers manage to skim off only the gains from good luck. Motivated by the corporate scandals in 2000 and the public opinion that CEOs are overpaid, I further examine the possibility that CEOs have captured the pay setting process and are paid for "luck" before SOX, however not after it when their corporate governance was presumably improved.

\section{Pay for Luck}

The analysis in Section 7 does not distinguish between earnings from company performance related to CEO activities and from "luck" that is attributed to events beyond the manager's control. In this section, I estimate whether CEOs pay depends on events 
beyond their control and how SOX affects such pay for luck. In a widely cited paper, Bertrand and Mullainathan (2001) explore empirically whether CEO pay depends on events beyond their control. The authors use year-to-year differences in mean industry performance to proxy for industry fortune. ${ }^{32}$ Naming the response of pay to changes in industry performance pay for luck, the authors document that the average executive receives compensation for industry performance. Garvey and Milbourn (2006) reason that this argument is incomplete because it can be also interpreted as compensation for bearing industry risk. They develop the pay-for-luck view by stressing the importance of bad luck versus good luck. If CEOs have managed to capture the pay setting process and to tie their pay to industry performance, then the link will be stronger when the benchmark is up than when it is down. I address the impact of SOX on both pay for good luck (when the industry is up) and pay for bad luck (when the industry is down).

My analysis of the effect of SOX on CEO pay for luck relies on the methodology proposed by Bertrand and Mullainathan (2001), and Garvey and Milbourn (2006). I estimate CEO pay for luck using a two-stage regression approach. In the first stage, I decompose the variation of firm performance into a component caused by the variation of average industry performance and a firm's specific performance. The residual from this decomposition represents skill, that is a firm-specific component combining CEO ability and other unobservable shocks. The average industry return employed as a regressor in the first stage is the weighted average rate of return on assets in a given year in the twodigit SIC industry that a firm belongs to, excluding the firm itself from the calculation. The weight of a given firm is the share of its assets in the total assets of the industry that the firm belongs to. In the second stage of the procedure, CEO pay is predicted using the industry-induced firm performance and firm-idiosyncratic performance estimated in the first stage.

Consistent with the skimming view, I expect improved monitoring after SOX to restrain CEOs' power to determine their own pay. Motivated by Bertrand and Mul-

\footnotetext{
${ }^{32}$ This study measures luck also by movement in oil prices in the oil industry and changes in industryspecific exchange rate for firms in the traded good sector. CEO pay responds to luck for all different measures.
} 
lainathan (2001) who show that paying for luck is weaker in firms with stronger corporate governance, I proxy the efficacy of corporate governance with board independence. CEOs are expected to better insulate themselves from bad luck outcomes when they are employed in a weak-governance firm, i.e., dependent board firm.

Table 7 presents selected coefficients from total-pay regressions on industry-induced ROA, firm-specific ROA and SOX interactions. ${ }^{33}$ The parameters of interest are the coefficient on industry-induced ROA, that is the predicted company return from the first-stage regression of company return on the average industry return on assets, and the corresponding SOX interaction (SOX*Industry-induced ROA). ${ }^{34}$ Looking at the fullsample column in Table 7, the point estimate for the predicted industry-induced ROA is 5 and for the firm-specific ROA it is 1.1 before SOX. These results confirm Bertrand and Mullainathan (2001) by documenting that before SOX the executive pay is positively and significantly related to both luck and firm-specific performance, that is a proxy for managerial talent. Further on, the sensitivities to luck and skill are statistically different, which suggests that benchmarking is an important feature of the average CEO compensation. ${ }^{35}$

\footnotetext{
${ }^{33}$ Bootstrapped standard errors are calculated at the first stage to account for the generated regressors at the second stage.

${ }^{34}$ This first-stage regression is reported in the Appendix, Table A3. An important choice in the empirical design is whether to allow the sensitivity of firm performance to peer performance to differ across firms. Bertrand and Mullainathan (2001), for example, include firm fixed effects in their firststage performance regressions. Estimating firm-specific betas, however, might introduce estimation error into the peer performance term in the second stage regression with two possible consequences. If the estimation error is simply noise, than the coefficient on peer performance in CEO pay regression is biased towards zero. If, on the other hand, the estimation error introduces elements of firm-specific performance into the estimated peer performance term, then I may erroneously document pay for luck. To insure against estimation error consequences, I estimate both firm-specific betas and common peer performance beta for all firms. The results in the Appendix consider firm fixed effects and cluster the residuals at the firm level or industry level (untabulated).

${ }^{35}$ If a firm does not distinguish pay for firm-specific return from pay for luck then we would expect both to be equally important components of the average CEO pay. Garvey and Milbourn (2006) show that equal sensitivity to both parameters might be due to optimal contracting arrangement than to
} 
CEOs pay for luck falls after SOX. The point estimates of the coefficients imply that for the average CEO, a percentage point increase in industry-induced ROA will decrease total compensation by $2.4 \%$, while a percentage point increase in firm-specific ROA will increase total pay by $0.62 \%$, which in no case is statistically different from the sensitivity to luck. Thus, across all firms pay for luck is present before SOX, however, such practice disappears after the reform. Looking at the firms with an independent board structure before SOX, it is noticeable that these firms do not pay for luck during the whole period; however, in the dependent board firms, where CEOs can influence to a greater extent the pay process, pay for luck exists before SOX and disappears after it. The evidence suggests that firms that are justified to be better governed do not pay for luck, and after the reform, managers are also not compensated for luck in firms with weaker governance before the reform.

Figure 3 demonstrates the pay-for-luck coefficients, with their $95 \%$ confidence intervals before/after SOX for independent/dependent boards received from Table 7. Clearly, before the reform CEOs in dependent board firms were rewarded for luck, while CEOs in independent board firms did not receive such payment. After SOX, the sensitivity of industry-induced performance to pay is insignificant.

\subsection{Asymmetric Response of Pay to Industry ROA}

In the next step, I explore pay for luck when the benchmark is positive or negative. Finding evidence for asymmetric benchmarking supports the view that CEOs are paid for luck than for bearing systematic risk by linking their pay to industry performance. Under the pay for luck case, CEO pay is sensitive to industry fortune but not to industry recession. I allow the sensitivity of pay to industry-induced ROA and firm-specific ROA (i.e., skill) to differ depending on whether luck or firm-specific ROA is up or down before and after SOX. Table 8 presents results before and after the reform for a positive and a negative industry return benchmark. Particularly, I add interactions with indicator variables taking values of one if industry-induced or firm-specific ROA is smaller than

skimming. Managers will not only choose to insure fully against luck but also to be rewarded for firm-specific performance. 
zero, and zero otherwise.

Table 9 present the total elasticities and their standard errors based on the results from Table 8. For the full sample, displayed in the upper panel of the table, the sensitivity of total pay to industry-induced ROA before SOX is significantly higher in booms, 5.9, than in recessions, 1.04 (Industry-induced ROA + Industry-induced ROA*Down), which means that managers are rewarded for good luck; however, they are insulated from bad luck before SOX. Further, I reject the hypothesis that the sensitivity of pay for bad luck and bad firm-induced ROA are equal; similarly for good luck and good firm-induced ROA. After SOX, the sensitivity of pay to industry-induced and firm-specific ROA disappears. Consistent with improved governance, after SOX pay for good skill (the positive residual from the first stage) increases as well as punishment for bad skill.

Looking at the second and third panel of the same table, independent board firms do not pay either for good or for bad luck over the entire 1998-2005 period. Dependent board firms, however seem to equally reward CEOs for good luck and punish them for bad luck, which is not preserved after the reform. Even though in the full-sample there is evidence of paying CEOs for luck, it appears that company board structure affects ambiguously the response of pay to industry-wide movements in performance.

The link between pay and industry-induced performance might be consistent with other economic perspectives. Demand-supply dynamics in the managerial labor market might play a role by increasing the demand for skilled CEOs during industry fortune, which results in higher compensation. Himmelberg and Hubbard (2000) argue that the supply of highly skilled CEOs is relatively inelastic, therefore shocks to aggregate demand increase both the value of the firm as well as the marginal value of the CEO pay. In other words, the dependence of pay to positive industry-wide return might be used to motivate the manager to stay with the company when facing the opportunity to receive a better outside option. If we believe that the link between CEO pay and industry return fluctuations is driven by demand-supply changes on the managerial labor market due to shocks, and particularly that during positive industry change, good CEOs are rewarded more for staying with the company, then we would expect positive shocks to affect this link consistently over time or demand-supply imbalances caused by booms to have a 
permanent effect. On the contrary, we see that the average CEO is rewarded more for positive shocks only before 2002 (Table 9).

Finally, one might believe that a CEO's actions and skills might affect industry performance through strategic interactions and oligopolistic industries (Aggarwal and Samwick, 1999). Thereby, fair CEO pay would be sensitive to industry performance. I evaluate whether the effect of industry performance on pay decreases as the industry definition broadens (as broader industries are less likely to be oligopolistic) and whether the effect is weaker for small firms (as small firms have weaker market power to affect the industry product market). There is no statistical difference between pay for luck coefficients when the industry is defined as a one-digit SIC or two-digit SIC. Further, the results (untabulated) clearly indicate that pay for luck in big firms is not statistically different from pay for luck in small firms. In sum, this evidence does not provide support for the argument that sensitivity of pay to industry return is due to strategic interactions.

Overall, the results provide evidence to conclude that some CEOs were rewarded for luck before SOX, while this practice is not observed after enforcing corporate governance rules in 2002. When accounting for asymmetric benchmarks, the results confirm pay for luck for all firms before SOX but not after it, which advocates the skimming view. However, this evidence is not fully consistent with the board structure, which is expected to reduce more effectively such type of pay in firms where more independent directors sit on the company board. Finally, Table 10 summarizes the effect of the reform. Even though SOX does not regulate directly CEO compensation contracts, board structure is the channel through which pay for performance and pay for luck are affected. After SOX, pay for performance is strengthened, while pay for luck has decreased in firms expected to be affected by the Act - these are, dependent board firms. To understand the overall impact of the reform, however, it is necessary to evaluate both benefits and costs. Particularly, monitoring and audit costs seem to be inflated the most by SOX. 


\section{Conclusion}

This paper examines the dynamics of executive pay before and after the corporate governance regulations of 2002. Introduced soon after a series of corporate scandals, the reforms mandated independent audit, nomination and compensation committees together with higher sanctions for management misconduct. Unlike Wang (2005) who focuses on a highly specific executive group - CFOs and COOs - my study covers CEOs and all other executives, thereby placing the analysis into the contemporary literature on CEO pay.

Employing a difference-in-differences methodology, I study jointly pay for performance and pay for luck. I compare before/after differences in two types of firms: those with stronger board monitoring before the reform and those with weaker board monitoring. Further, assuming that non-CEOs would not be affected by SOX, the analysis compares CEO pay for performance to that of non-CEOs across different boards.

I find that the pay-for-performance link increases after 2002 in firms with weaker board oversight, that is, in firms more affected by SOX stipulations. In contrast, the pay-for-performance relationship changes little in firms with independent boards. NonCEO pay for performance remains stable over the whole period. These results cannot be explained by the standard economic theory of executive compensation - the principalagent model — which motivates exploration on an alternative view, namely the "skimming view."

Following Bertrand and Mullainathan (2001), I examine CEO pay for luck before and after SOX. Consistent with this study, I document that after the reform, when corporate governance is improved, pay for luck measured by industry-wide movements in firm performance disappears on average. Further, to uncover the effect of governance on pay for luck, I explore separately its before/after reform change for different boards, and positive and negative industry shocks. Consistent with the "skimming" hypothesis, CEOs are rewarded only for positive industry shocks before SOX, but they are not punished for negative ones. These results confirm the earlier finding of Bertrand and Mullainathan (2001) that stronger corporate governance decreases pay for luck, which undermines shareholders's value. The contribution of my analysis is that I employ a different identification approach to answer how the recent governance reform affects pay 
for luck. Combining the pay for performance and pay for luck explorations, I find that in the dependent board firms the first component increases and the second one decreases after SOX, which supposedly is an indicator of improved corporate governance. The policy implication is that stricter corporate governance rules insured by the SarbanesOxley Act of 2002, might be beneficial for shareholders because they manage to curb CEOs' rent-seeking behavior. To evaluate the total effect of the corporate governance reforms of 2002, however, is necessary to account for the costs of SOX - increased audit fees - which is left for future research.

\section{Bibliography}

Aggarwal, R. and A. Samwick (1999a) "The Other Side of the Trade-off: the Impact of Risk on Executive Compensation," Journal of Political Economy 107, 65-105.

Aggarwal, R. and A. Samwick (1999b) "Executive Compensation, Strategic Competition, and Relative Performance Evaluation: Theory and Evidence," Journal of Finance 54, 1999-2043.

Almazan, A. and J. Suarez (2003) "Entrenchment and Severance Pay in Optimal Governance Structures," Journal of Finance, 47, 519-548.

Bebchuk L. and J. Fried (2004) "Pay Without Performance: The Unfulfilled Promise of Executive Compensation," Cambridge, Harvard University Press.

Bebchuk L. and Y. Grinstein (2005) "The Growth of Executive Pay, Oxford Review of Economic Policy," 21, 2.

Bebchuk, L.A., J. Fried and D. Walker (2003) "Executive Managerial Power and Rent Extraction in the Design of Executive Compensation, University of Chicago Law Review 69," 751-846.

Becht, M., P. Bolton and A. Roell (2002) "Corporate Governance and Control," ECGN Working Paper.

Bertrand, M. and S. Mullainathan (2001) "Are CEOs Rewarded for Luck? The Ones Without Principals Are," The Quarterly Journal of Economics, 116(3), 901-32.

Bertrand, M. and S. Mullainathan (1998) "Executive Compensation and Incentives: The Impact of Takeover Legislation," NBER Working Paper 6830.

Cohen D., A. Dey and Th. Lys (2004) "The Sarbanes Oxley Act of 2002: Implications for Compensation Structure and Risk-Taking Incentives of CEOs," Working Paper, Northwestern University. 
Conyon M. (2006) "Executive Compensation and Incentives," Academy of Management Perspectives, 20, 25-44.

Core, J. (2002) "Discussion of The Roles of Performance Measures and Monitoring in Annual Governance Decisions in Entrepreneurial Firms," Journal of Accounting Research, 40, 2, 519-527.

Core, J. and W. Guay (1999) "The Use of Equity Grants to Manager Optimal Equity Incentive Levels," Journal of Accounting and Economics, 28, 151-184.

Core, J., R.W. Holthausen and D. Larcker (1999) "Corporate Governance, CEO compensation, and firm performance," Journal of Financial Economics, 51, 371-406.

Core, J., W. Guay and D. Larcker (2003) "Executive Equity Compensation and Incentives: A Survey," Economic Policy Reveiw, April, 27-50.

Daily, C., J. L. Johnson, A. E. Ellstrand and D. R. Dalton (1998) "Compensation Committee Composition as a Determinant of CEO Compensation," The Academy of Management Journal, Vol. 41, No. 2, 209-220.

Demsetz and Lehn (1985) "The Structure of Corporate Ownership: Causes and Consequences," Journal of Political Economy, 1155-1177.

Fich, E. and A. Shivdasani (2006) "Are Busy Boards Effective Monitors?," Journal of Finance, 61, 689-724.

Garvey G. and T. Milbourn (2006) "Asymmetric Benchmarking in Compensation: Executives are Rewarded for Good Luck but not Penalized for Bad," Journal of Financial Economics, 82, 197-225.

Gibbon, R. and K. J. Murphy (1992) "Optimal Incentives Contracts on the Presence of Career Concerns: Theory and Evidence," Journal of Political Economy, 100, 468-505.

Gimein, M. (2002) "You Bought. They Sold," Fortune, Sep. 2, 2002.

Grinstein, Y. and P. Hribar(2004), CEO Compensation and Incentives: Evidence From M\&A bonuses," Journal of Financial Economics, 73, 119-143.

Heckman J. and Hotz (1989) "Choosing Among Alternative Non-experimental Methods For Estimating The Impact of Social Programs: The Case of Manpower Training," Journal of the American Statistical Association, 84(408), 862-874.

Hall, B. and J. Liebman (1998) "Are CEOs Really Paid Like Bureaucrats?," Quarterly Journal of Economics, 103, 653-91.

Hallock, K. (1997) "Reciprocally Interlocking Boards of Directors and Executive Compensation," Journal of Financial and Quantitative Analysis, 32, 331-344. 
Hart, O. and B. Holmstrom (1987) "The Theory of Contracts," In Advances in Economic Theory, Fifth World Congress (ed. T. Bewley), Cambridge University Press.

Hartzell, J. C. (2001) "The Impact of the Likelihood of Turnover on Executive Compensation," Working Paper, University of Texas at Austin.

Hartzell, J. C. and L. Starks (2002) "Institutional investors and executive compensation," Journal of Finance, Vol. 58, 2351-2374.

Hermalin, B.E. and Weisbach, M.S. (2003) "Boards of Directors as an Endogenously Determined Institution: A Survey of the Economic Literature," Economic Policy Review, 9, 7-26.

Hilzenrath, D.S., J. Weisman, and J. Vandehei (2002) "How Congress Rode a 'Storm' to Corporate Reform," The Washington Post, July 28, 2002.

Himmelberg, C. P. and Hubbard and R. Glenn (2000) "Incentive Pay and the Market for CEOs: An Analysis of Pay-For-Performance Sensitivity," Working Paper, Columbia University.

Holmstrom, B. (1979) "Moral Hazard and Observability," Bell Journal of Economics, $13,234-340$.

Hubbard, R. and D. Palia (1995) "Executive Pay and Performance: Evidence from the US Banking Industry," Journal of Financial Economics, 39, 105-130.

Holmstrom, B. and S. Kaplan (2003) "The State of U.S. Corporate Governance: What's Right and What's Wrong?," University of Chicago.

Kole, S.R. (1997) "The Complexity of Compensation Contracts," Journal of Financial Economics, 43, 79-104.

Jensen, M. C. and W. Meckling (1976) "Theory of the Firm: Managerial Behavior, Agency Costs and Ownership Structure," Journal of Financial Economics, 3, 30560.

Jensen, M.C. and K. J. Murphy (1990) "Performance Pay and Top-management Incentives," Journal of Political Economy, 98, 225-264.

Linck J., J. Netter and T. Yang (2005) "Effects and Unintended Consequences of the Sarbanes-Oxley Act on Corporate Boards, Working Paper," University of Georgia.

Leonard, J. (1990) "Executive Pay and Firm Performance," Industrial and Labor Relations Review, 43, 13S-29S.

Murphy K. (1999) "Executive Compensation," In O.Ashenfelter and D. Card (eds), Handbook of Labor Economics, Volume 3, North Holland, 2485-2525. 
Ofek E. and D. Yermack (2000) "Taking Stock: Equity-Based Compensation and the Evolution of Managerial Ownership," Journal of Finance, 55, 1367-1384.

Sloan, R. (1993) "An Examination of the Role of Accounting Earnings in Top Executive Compensation Contracts," Journal of Accounting and Economics, 16, 55-100.

VandeHei, J. and D.S. Hilzenrath (2002) "Hill Leaders Agree on Corporate Curbs; Attack on Fraud Includes Auditing Control and Jail Terms," The Washington Post, July 25, 2002.

Yermack, D. (1996) "Higher Market Valuation of Companies with a Small Board of Directors," Journal of Financial Economics, 40, 185-211.

Wang X. (2005) "The Impact of the Corporate Governance Reform Initiatives on Chief Financial Officer Compensation," Working Paper, University of Chicago. 
Table 1: Governance Patterns: Board Characteristics

\begin{tabular}{llllll}
\hline & 1998 & 2001 & 2002 & 2004 & Test \\
\hline Employee directors $^{1}$ & 0.22 & 0.21 & 0.19 & 0.17 & $*$ \\
Linked directors $^{2}$ & 0.18 & 0.16 & 0.12 & 0.12 & $*$ \\
Independent directors $^{3}$ & 0.6 & 0.63 & 0.67 & 0.7 & $*$ \\
Independent nominating committee $^{4}$ & 0.72 & 0.75 & 0.79 & 0.91 & $*$ \\
Independent compensation committee $^{5}$ & 0.85 & 0.87 & 0.9 & 0.94 & $*$ \\
Independent audit committee $^{6}$ & 0.82 & 0.88 & 0.9 & 0.95 & $*$ \\
Majority independent members $^{7}$ & 0.67 & 0.71 & 0.77 & 0.88 & $*$ \\
Busy directors $^{8}$ & 0.20 & 0.16 & 0.15 & 0.15 & $*$ \\
Board size $_{\text {Annual director's fees (\$thousands) }}{ }^{9}$ & 9.62 & 9.25 & 9.38 & 9.37 & $*$ \\
Number of board meetings per year & 7.25 & 19.95 & 21.98 & 29.78 & $*$ \\
\hline
\end{tabular}

Notes: The last column shows the significance of the non-parametric binomial test of differences in probabilities for 2004 and 1998. * denotes statistical significance at 1\%. Board summary characteristics come from IRRC (full sample). The database identifies three types of board affiliation: employee, linked (director who provides professional services to the company or is a major customer including former employees and recipients of charitable funds; interlocks, and family member of a director or executive), and independent (no significant connection with the firm).

${ }^{1},{ }^{2}$ and ${ }^{3}$ measure the percentage of employee, linked, and independent directors, respectively.

${ }^{4},{ }^{5}$ and ${ }^{6}$ show the share of independent directors from the total number of committee members who sit on nominating, compensation and audit committees, respectively.

7 reports the share of firms with more than $50 \%$ independent directors.

8 shows the share of directors serving on more than 3 boards in a given year.

${ }^{9}$ is available in the ExecuComp data. 
Table 2: Sample Overview

$\begin{array}{lllllllll}1998 & 1999 & 2000 & 2001 & 2002 & 2003 & 2004 & 2005 & \text { Total }\end{array}$

\section{ExecuComp}

Number of Firms

1,941

Chief Executive Officers (CEO)

1,844

1,795

1,825

1,801

1,784

1,650

14,592

Chief Operating Officer $(\mathrm{COO})$

1,731

1,810

1,792

1,671

1,671

1,688

1,690

13,702

Chief Financial Officer (CFO)

1,161

805

878

822

849

827

804

778

6,547

All the rest

9,005

1,271

1,358

1,327

1,376

1,398

1,416

1,451

10,758

\section{IRRC}

Number of Firms

$\begin{array}{lllllllll}1,770 & 1,804 & 1,755 & 1,797 & 1,439 & 1,472 & 1,477 & \text { n/a } & 11,514 \\ 17,046 & 17,419 & 16,675 & 16,669 & 13,498 & 13,792 & 13,733 & \text { n/a } & 108,832\end{array}$

Directors

Number of Firms

1,170

1,244

$1,297 \quad 1,349 \quad 1,340 \quad 1,373 \quad 1,342$

9,115

Note: ExecuComp and IRRC samples include all present firms. IRRC data is not available for 2005

(October 2006 version). 
Table 3: CEO Pay Pattern: Percentage Changes Before and After SOX

\begin{tabular}{llllll}
\hline & Firms & $\begin{array}{l}\text { Salary } \\
\text { and Bonus }\end{array}$ & $\begin{array}{l}\text { Option } \\
\text { Value }\end{array}$ & $\begin{array}{l}\text { Restricted } \\
\text { Stock }\end{array}$ & $\begin{array}{l}\text { Total } \\
\text { Pay }\end{array}$ \\
\hline All firms & 13,216 & $0.26^{* * *}$ & -0.03 & $0.4^{* * *}$ & $0.16^{* * *}$ \\
Industry & & & & & \\
Mining and Manufacturing & 2,851 & $0.29^{* * *}$ & $0.11^{* *}$ & $0.49^{* * *}$ & $0.28^{* * *}$ \\
Finance and Insurance & 1,812 & $0.15^{* * *}$ & $-0.30^{* * *}$ & 0.19 & -0.02 \\
Utilities & 800 & $0.22^{* * *}$ & 0.12 & $0.50^{* * *}$ & $0.22^{* *}$ \\
Services & 1,958 & $0.32^{* * *}$ & $-0.14^{* *}$ & 0.16 & $0.12^{*}$ \\
Other & 5,795 & $0.22^{* * *}$ & -0.04 & 0.46 & $0.14^{* * *}$ \\
Market Index & & & & & \\
S\&P 500 & 3,618 & $0.26^{* * *}$ & $-0.09^{* *}$ & $0.38^{* * *}$ & $0.16^{* * *}$ \\
S\&P MidCap 400 & 2,598 & $0.29^{* * *}$ & 0.4 & $0.6^{* * *}$ & $0.28^{* * *}$ \\
S\&P SmallCap 600 & 3,271 & $0.24^{* * *}$ & $0.10^{* *}$ & $0.34^{* * *}$ & $0.20^{* * *}$ \\
Other & 3,729 & $0.12^{* * *}$ & $-0.17^{* * *}$ & $0.29^{* * *}$ & -0.05 \\
Board Structure & & & & & \\
Independent & 5,763 & $0.25^{* * *}$ & -0.01 & $0.43^{* * *}$ & $0.17^{* * *}$ \\
Dependent & 4,954 & $0.28^{* * *}$ & 0.01 & $0.4^{* * *}$ & $0.21^{* * *}$ \\
\hline
\end{tabular}

Note: The sample includes all ExecuComp firms. Summary statistics of compensation show percentage change from 2002-2005 to 1998-2001. *** Significant at the $1 \%$ level; ${ }^{* *}$ Significant at $5 \%$; ${ }^{*}$ Significant at $10 \%$. Option value is the aggregate value of stock options granted to executives during the year as valued using S\&P's Black-Scholes Methodology. Restricted stock is the value of restricted stock granted during the year. Total Pay is comprised of salary and bonus, other annual income, total value of restricted stock granted, total value of stock options, longterm incentives payouts and all other pay. The division of board independence is based on the percentage of independent directors on the board: 10 portfolios are formed based on firms sales. For each portfolio, independent boards are those with above the portfolio median independence percentage. 
Figure 1: Mean CEO Pay, 1998-2005

Note: Figure 1 shows mean CEO pay for all firms in ExecuComp data.

Total pay includes salary and bonus, other annual pay, total value of restricted stock granted, total value of stock options, long-term incentives and all other pay. Option value is the aggregate value of stock options granted to executives during the year as valued using S\&P's Black-Scholes Methodology. Restricted stock is the value of restricted stock granted during the year.

Table 4: Board Structures Percentage Change Before/After SOX

\begin{tabular}{lllllll}
\hline & \multicolumn{4}{l}{ Median-Portfolio-Based $^{1}$} & \multicolumn{3}{l}{ Majority-Based $^{2}$} \\
\cline { 2 - 7 } & Independ. & Depend. & $\Delta$ & Independ. & Depend. & $\Delta$ \\
\hline Independent audit committee $^{3}$ & 0.03 & 0.22 & 0.19 & 0.05 & 0.24 & 0.19 \\
Independent nomination committee $^{4}$ & 0.14 & 0.45 & 0.31 & 0.17 & 0.57 & 0.4 \\
Independent compensation committee $^{5}$ & $0.01+$ & 0.19 & 0.18 & 0.02 & 0.27 & 0.25 \\
Number of board meetings $^{\text {Numyyyyy}}$ & 0.07 & 0.14 & 0.07 & 0.07 & 0.19 & 0.12 \\
\hline
\end{tabular}

Notes: Summary statistics show percentage change from 2002-2004 to 1998-2001 for alterative proxies for board affiliation. + denotes statistically insignificant at any conventional level. All other statistics are significant at $1 \%$.

${ }^{1}$ Board independence is based on the percentage of independent directors on the board: 10 portfolios are formed based on firms sales. For each portfolio, independent boards are those with above the median independence percentage.

${ }^{2}$ Boards with more than $50 \%$ independent directors.

${ }^{3},{ }^{4}$ and ${ }^{5}$ report independent directors as a fraction of the total number of committees members who sit on audit, nomination and compensation committee, respectively. 


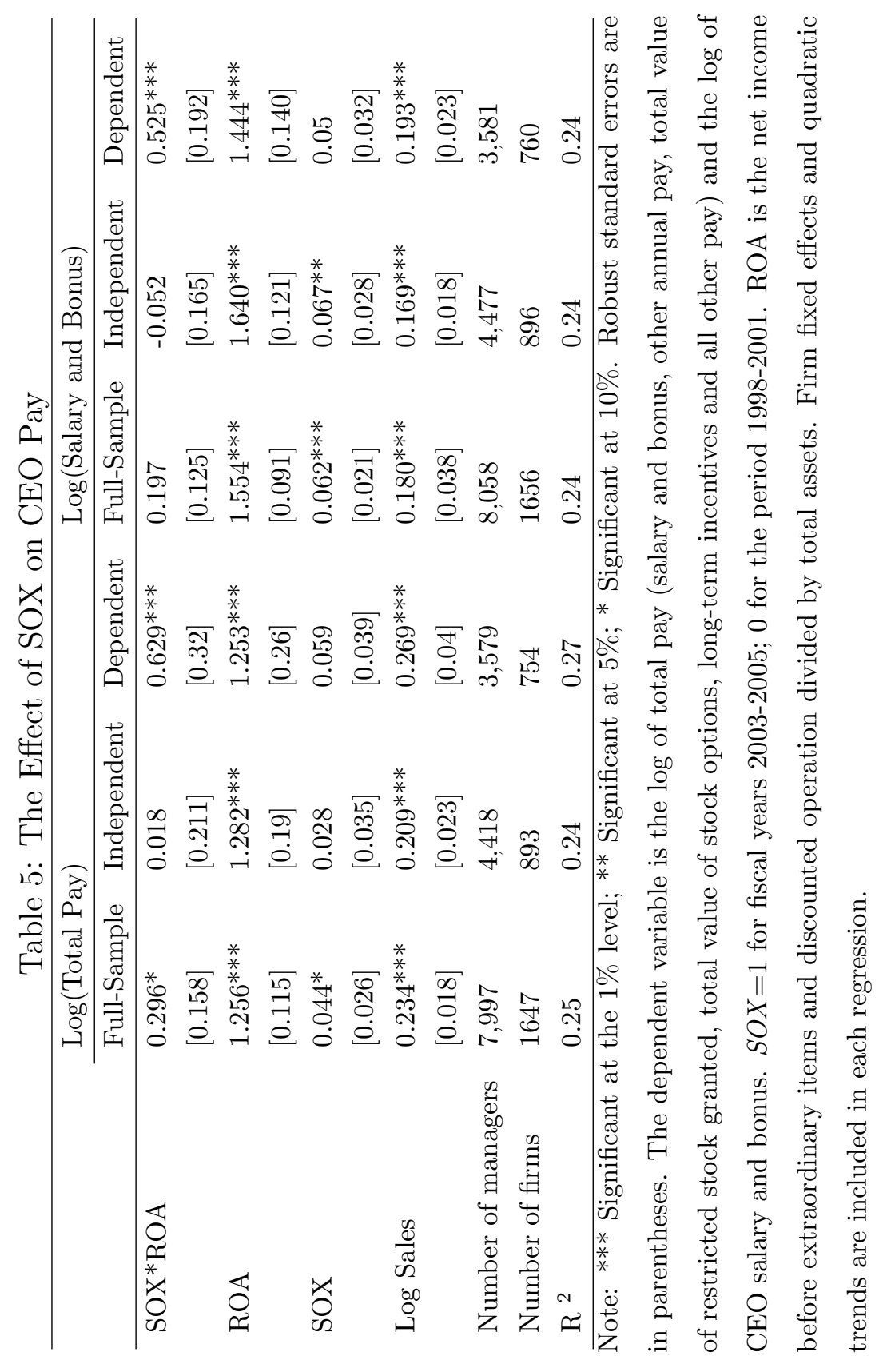




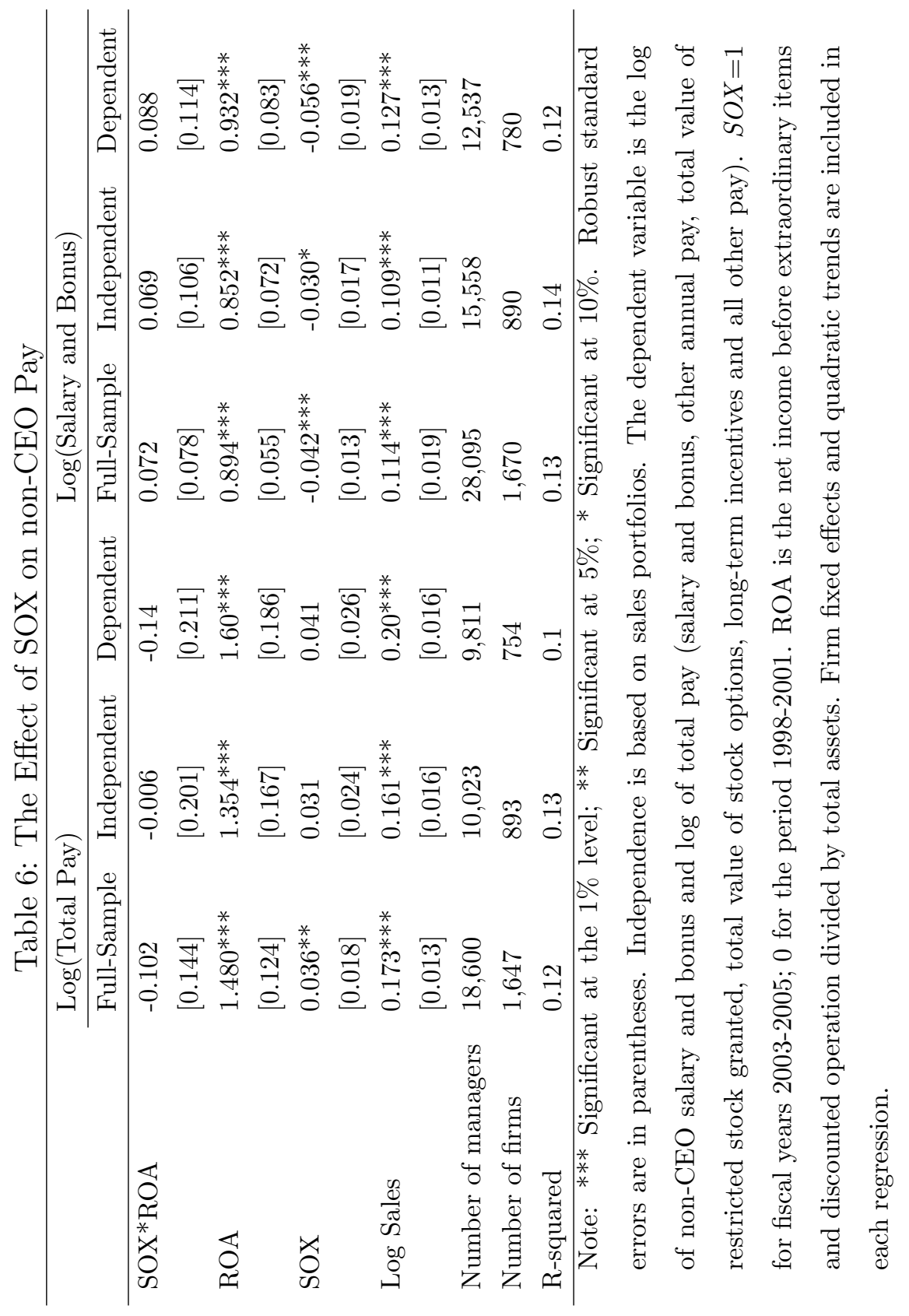


Figure 2: Pay-For-Performance Coefficients

Note: Figure 2 shows the estimated pay-for-performance coefficients with their corresponding 95\% confidence intervals. Each coefficient comes from a separate regression: estimates for the CEOs are from Table 5 and for non-CEOs from Table 6 . The dependent variable is the log of CEO total pay, which is comprised of salary and bonus, other annual pay, total value of restricted stock granted, total value of stock options, long-term incentives and all other pay. Performance is measured with ROA that is the net income before extraordinary items and discounted operation divided by total assets. 
Table 7: CEO Pay for Luck: Total Effect

\begin{tabular}{llll}
\hline & \multicolumn{3}{c}{ Log(Total Pay) } \\
\cline { 2 - 4 } & Full-Sample & Independent & Dependent \\
\hline Industry-induced ROA & 5.097 & 1.423 & $14.669^{* * *}$ \\
& {$[3.33]$} & {$[3.88]$} & {$[4.46]$} \\
Firm-specific ROA & $1.097^{* * *}$ & $1.247^{* * *}$ & $0.927^{* * *}$ \\
& {$[0.174]$} & {$[0.266]$} & {$[0.276]$} \\
SOX*Industry-induced ROA & -2.403 & -0.497 & $-8.826^{*}$ \\
& {$[3.170]$} & {$[3.959]$} & {$[5.228]$} \\
SOX*Firm-specific ROA & $0.626^{* *}$ & 0.008 & $1.441^{* * *}$ \\
& {$[0.31]$} & {$[0.327]$} & {$[0.393]$} \\
SOX & -0.648 & -0.293 & $-1.918^{*}$ \\
& {$[0.617]$} & {$[0.791]$} & {$[1.41]$} \\
Log Sales & $0.22^{* * *}$ & $0.25^{* *}$ & $0.16^{*}$ \\
\multirow{2}{*}{ Number of managers } & {$[0.10]$} & {$[0.11]$} & {$[0.09]$} \\
Number of firms & 7,986 & 4,415 & 3,571 \\
$\mathrm{R}^{2}$ & 1,644 & 892 & 752 \\
\hline Note*** Sigif & 0.25 & 0.24 & 0.27 \\
\hline
\end{tabular}

Note: ${ }^{* * *}$ Significant at the $1 \%$ level; ${ }^{* *}$ Significant at $5 \% ; *$ Significant at $10 \%$. Robust standard errors are in parentheses. Independence is based on sales portfolios. The dependent variable is the log of CEO total pay, which is comprised of salary and bonus, other annual pay, total value of restricted stock granted, total value of stock options, long-term incentives and all other pay. Before SOX covers 1998-2001, After SOX covers 2003-2005. Return is net income before extraordinary items and discounted operation divided by total assets (ROA). Industry-induced ROA is the predicted company return from a first stage regression with average industry return (asset-weighted industry ROA in the firm's 2digit SIC industry, where the firm itself is excluded from the mean calculation). Firm-specific ROA is the residual from the same regression as the industry-induced ROA. Each regression includes trend, quadratic trend, sales, constant and firm fixed effects. 
Figure 3: Pay-For-Luck Coefficients

Note: Figure 3 shows the estimated pay-for-luck coefficients with their corresponding $95 \%$ confidence intervals. The dependent variable is the $\log$ of CEO total pay, which is comprised of salary and bonus, other annual pay, total value of restricted stock granted, total value of stock options, long-term incentives and all other pay. Return is the net income before extraordinary items and discounted operation divided by total assets (ROA). Industry-induced return is predicted company return from a first stage regression with average industry return (assetweighted industry ROA in the firm's 2-digit SIC industry, where the firm itself is excluded from the mean calculation). 
Table 8: CEO Pay for Luck: Asymmetric Benchmarking

\begin{tabular}{|c|c|c|c|}
\hline & \multicolumn{3}{|c|}{ Log(Total Pay) } \\
\hline & Full-Sample & Independent & Dependent \\
\hline \multirow[t]{2}{*}{ Industry-induced ROA } & 5.849 & 2.051 & $15.833^{* * *}$ \\
\hline & {$[3.91]$} & {$[4.11]$} & {$[4.72]$} \\
\hline \multirow[t]{2}{*}{ Firm-specific ROA } & $1.840^{* * *}$ & $1.640^{* * *}$ & $2.146^{* * *}$ \\
\hline & {$[0.31]$} & {$[0.51]$} & {$[0.45]$} \\
\hline \multirow[t]{2}{*}{ Industry-induced ROA*Down } & $-4.805^{* *}$ & $-5.460 * *$ & -2.904 \\
\hline & {$[1.91]$} & {$[2.606]$} & {$[2.535]$} \\
\hline \multirow[t]{2}{*}{ Firm-specific ROA*Down } & $-1.281^{* *}$ & -0.638 & $-2.117^{* *}$ \\
\hline & {$[0.646]$} & {$[0.773]$} & {$[0.802]$} \\
\hline \multirow[t]{2}{*}{ SOX*Industry-induced ROA } & -3.097 & -0.963 & $-10.137^{*}$ \\
\hline & {$[3.426]$} & {$[3.889]$} & {$[4.01]$} \\
\hline \multirow[t]{2}{*}{ SOX*Firm-specific ROA } & 0.419 & -0.008 & 0.859 \\
\hline & {$[0.644]$} & {$[0.613]$} & {$[1.037]$} \\
\hline \multirow[t]{2}{*}{ SOX*Industry-induced ROA*Down } & $3.214^{* *}$ & 3.065 & 3.383 \\
\hline & {$[1.493]$} & {$[2.22]$} & {$[2.143]$} \\
\hline \multirow[t]{2}{*}{ SOX*Firm-specific ROA*Down } & 0.347 & -0.022 & 0.969 \\
\hline & {$[0.915]$} & {$[0.887]$} & {$[1.39]$} \\
\hline \multirow[t]{2}{*}{ SOX } & -0.667 & -0.293 & $-2.022^{* *}$ \\
\hline & {$[0.624]$} & {$[0.779]$} & {$[0.787]$} \\
\hline \multirow[t]{2}{*}{ Log Sales } & $0.23^{* * *}$ & $0.27^{*}$ & $0.16^{*}$ \\
\hline & 0.08 & {$[0.13]$} & {$[0.10]$} \\
\hline Number of managers & 7,986 & 4,415 & 3,571 \\
\hline Number of firms & 1,644 & 892 & 752 \\
\hline $\mathrm{R}^{2}$ & 0.26 & 0.24 & 0.28 \\
\hline
\end{tabular}

Robust standard errors are in parentheses. Independence is based on sales portfolios.

The dependent variable is the log of CEO total pay, which is comprised of salary and bonus, other annual pay, total value of restricted stock granted, total value of stock options, long-term incentives and all other pay. Before SOX covers 1998-2001, After SOX covers 2003-2005. Industry-induced ROA is the predicted company return from a first stage regression with average industry return (asset-weighted industry ROA in the firm's 2-digit SIC industry, where the firm itself is excluded from the mean calculation). Firm-specific ROA is the residual from the same regression as the industry-induced ROA. Down is an indicator variable taking the value of 1 if industry-induced ROA is negative and 0 otherwise; similarly for firm-specific ROA. Each regression includes trend, quadratic trend, sales, constant and firm fixed effects. 
Table 9: Total Sensitivity Effects

\begin{tabular}{|c|c|c|c|c|}
\hline & Good Luck & Bad Luck & Good Skill & Bad Skill \\
\hline & & Full-Sample & & \\
\hline \multirow[t]{2}{*}{ Before } & $5.849^{*}$ & 1.04 & $1.840^{* * *}$ & $0.55^{*}$ \\
\hline & {$[3.912]$} & {$[4.52]$} & [0.31] & [0.397] \\
\hline \multirow[t]{2}{*}{ After } & 2.75 & 1.16 & $2.25^{* * *}$ & $1.32^{* * *}$ \\
\hline & {$[2.83]$} & {$[3.17]$} & {$[0.60]$} & {$[0.416]$} \\
\hline & & Independent & & \\
\hline \multirow[t]{2}{*}{ Before } & 2.051 & -3.4 & $1.640^{* * *}$ & $1.00^{* *}$ \\
\hline & {$[4.11]$} & {$[4.69]$} & {$[0.51]$} & {$[0.38]$} \\
\hline \multirow[t]{3}{*}{ After } & 1.08 & -1.3 & $1.63^{* *}$ & $0.97^{* *}$ \\
\hline & {$[3.25]$} & [4.14] & {$[0.52]$} & {$[0.457]$} \\
\hline & & Dependent & & \\
\hline \multirow[t]{2}{*}{ Before } & $15.83^{* * *}$ & $12.92^{* * *}$ & $2.15^{* * *}$ & 0.02 \\
\hline & {$[4.72]$} & [4.89] & {$[0.545]$} & {$[0.478]$} \\
\hline \multirow[t]{2}{*}{ After } & 5.69 & 6.17 & $3.00^{* * *}$ & $1.85^{* * *}$ \\
\hline & {$[3.98]$} & {$[5.15]$} & {$[0.859]$} & {$[0.49]$} \\
\hline
\end{tabular}

Significant at $10 \%$. Robust standard errors are in parentheses.

Independence is based on sales portfolios. Each panel represents

a separate specification from Table 8 .

Table 10: The Effect of SOX

\begin{tabular}{lll}
\hline & Pay-for-Luck & Pay-for-Performance \\
\hline Dependent & $-8.826^{*}$ & $1.441^{* * *}$ \\
& {$[5.226]$} & {$[0.393]$} \\
Independent & -0.497 & 0.008 \\
& {$[3.959]$} & {$[0.327]$} \\
\hline$\Delta$ & $-8.32^{*}$ & $1.43^{* *}$ \\
{$[5.02]$} & {$[0.54]$} \\
\hline Note: ${ }^{* * *}$ Significant at the $1 \%$ level; ${ }^{* *}$ Significant \\
at $5 \%$; ${ }^{*}$ Significant at $10 \%$. & Robust standard errors \\
are in parentheses. $\Delta$ is the row difference between the \\
treated group (dependent) and the control group (inde- \\
pendent). Each coefficient is the before/after elasticity \\
change in Table 7.
\end{tabular}




\section{APPENDIX}

Table A1: Firm Patterns Across Years

\begin{tabular}{llcccccccc}
\hline & & 1998 & 1999 & 2000 & 2001 & 2002 & 2003 & 2004 & 2005 \\
\hline \multirow{3}{*}{ ROA } & & 1998 & 1999 & 2000 & 2001 & 2002 & 2003 & 2004 & 2005 \\
\multirow{3}{*}{ Stock Return } & Mean & 3.54 & 3.79 & 3.41 & 1.28 & 1.32 & 2.46 & 3.87 & 4.56 \\
& Median & 4.1 & 4.17 & 3.98 & 2.71 & 3.03 & 3.36 & 4.23 & 4.66 \\
Sales & Mean & 19 & 18 & 29 & 23 & -3 & 50 & 25 & 0.16 \\
& Median & 10 & 3 & 22 & 14 & -5 & 39 & 21 & 0.08 \\
& Mean & 3,751 & 3,961 & 4,492 & 4,837 & 4,637 & 4,946 & 5,486 & 6,500 \\
& Median & 1,090 & 1,014 & 1,097 & 1,177 & 1,134 & 1,191 & 1,320 & 1,754 \\
\hline
\end{tabular}

Notes: Return on assets (ROA) is the net income before extraordinary items divided by total assets. Return is the annualized monthly stock returns. Sales (in millions of USD) is the net annual sales as reported by the company. ROA and Return are reported in percent.

Table A2: Robustness to Board Independence

\begin{tabular}{lllllll}
\hline & \multicolumn{2}{l}{ Percentile ranges } & \multicolumn{3}{l}{ Majority Independence } \\
\cline { 2 - 7 } & $\leq 25$ th & $25 / 50$ th & $50 / 75$ th & $\geq 75$ th & Yes & No \\
\hline SOX*ROA & $0.466^{*}$ & $0.938^{* * *}$ & 0.141 & -0.241 & $0.457^{*}$ & 0.179 \\
& {$[0.26]$} & {$[0.333]$} & {$[0.311]$} & {$[0.308]$} & {$[0.24]$} & {$[0.182]$} \\
ROA & $1.062^{* * *}$ & $1.456^{* * *}$ & $1.141^{* * *}$ & $1.365^{* * *}$ & $1.153^{* * *}$ & $1.312^{* * *}$ \\
& {$[0.241]$} & {$[0.216]$} & {$[0.237]$} & {$[0.235]$} & {$[0.237]$} & {$[0.132]$} \\
SOX & 0.047 & 0.009 & 0.03 & 0.067 & 0.065 & 0.038 \\
Log Sales & {$[0.056]$} & {$[0.052]$} & {$[0.051]$} & {$[0.051]$} & {$[0.054]$} & {$[0.030]$} \\
& $0.320^{* * *}$ & $0.153^{* * *}$ & $0.198^{* * *}$ & $0.268^{* * *}$ & $0.326^{* * *}$ & $0.209^{* * *}$ \\
Number of managers & 1,867 & 1,965 & 2,084 & 2,082 & 1,932 & 5,987 \\
Number of firms & 417 & 389 & 417 & 424 & 432 & 1,213 \\
$\mathrm{R}^{2}$ & 0.28 & 0.26 & 0.25 & 0.23 & 0.29 & 0.24 \\
\hline
\end{tabular}

Notes: The dependent variable is the log of CEO total pay, which is comprised of salary and bonus, other annual pay, total value of restricted stock granted, total value of stock options, long-term incentives and all other pay. $S O X=1$ for fiscal years 2003-2005; 0 for the period 1998-2001. ROA is the net income before extraordinary items and discounted operation divided by total assets. Firm fixed effects and quadratic trend are included in each regression. Majority Independence board firms are with more than $50 \%$ independent directors. ${ }^{* *}$ Significant at the $1 \%$ level; ${ }^{* *}$ Significant at $5 \% ;{ }^{*}$ Significant at $10 \%$. 
Table A3: First-Stage Regression

\begin{tabular}{|c|c|}
\hline & Firm ROA \\
\hline \multirow[t]{2}{*}{ Industry-induced ROA } & $1.255^{* * *}$ \\
\hline & {$[0.317]$} \\
\hline \multirow[t]{2}{*}{ SOX } & $0.007^{* *}$ \\
\hline & {$[0.003]$} \\
\hline \multirow[t]{2}{*}{ Log Sale } & $0.031^{* * *}$ \\
\hline & {$[0.002]$} \\
\hline \multirow[t]{2}{*}{ Trend } & $-5.325^{* * *}$ \\
\hline & {$[0.564]$} \\
\hline \multirow[t]{2}{*}{ Trend2 } & $0.001^{* * *}$ \\
\hline & {$[0.000]$} \\
\hline Number of managers & 9,200 \\
\hline Number of firms & 1,711 \\
\hline $\mathrm{R}^{2}$ & 0.06 \\
\hline \multicolumn{2}{|c|}{ *** Significant at the $1 \%$ level; ${ }^{* *}$ Significant at $5 \%$; } \\
\hline \multicolumn{2}{|c|}{ cant at $10 \%$. This is the first stage regression used in all } \\
\hline \multicolumn{2}{|c|}{ The dependent variable is ROA, measured with the net } \\
\hline \multirow{2}{*}{\multicolumn{2}{|c|}{$\begin{array}{l}\text { me before extraordinary items and discounted operation } \\
\text { ded by total assets. Before SOX covers 1998-2001, After }\end{array}$}} \\
\hline & \\
\hline \multicolumn{2}{|c|}{$X$ covers 2003-2005. Industry-induced $R O A$ is the average } \\
\hline \multicolumn{2}{|c|}{ et-weighted industry return on assets in the firm's 2-digit } \\
\hline try, where the firm itself is & excluded from the meat \\
\hline
\end{tabular}


Individual researchers, as well as the on-line and printed versions of the CERGE-EI Working Papers (including their dissemination) were supported from the following institutional grants:

- Center of Advanced Political Economy Research [Centrum pro pokročilá politickoekonomická studia], No. LC542, (2005-2009),

- Economic Aspects of EU and EMU Entry [Ekonomické aspekty vstupu do Evropské unie a Evropské měnové unie], No. AVOZ70850503, (2005-2010);

- Economic Impact of European Integration on the Czech Republic [Ekonomické dopady evropské integrace na ČR], No. MSM0021620846, (2005-2011);

Specific research support and/or other grants the researchers/publications benefited from are acknowledged at the beginning of the Paper.

(c) Teodora Paligorova, 2007

All rights reserved. No part of this publication may be reproduced, stored in a retrieval system or transmitted in any form or by any means, electronic, mechanical or photocopying, recording, or otherwise without the prior permission of the publisher.

Published by

Charles University in Prague, Center for Economic Research and Graduate Education (CERGE) and

Economics Institute ASCR, v. v. i. (EI)

CERGE-El, Politických vězňů 7, 11121 Prague 1, tel.: +420 224005 153, Czech Republic.

Printed by CERGE-EI, Prague

Subscription: CERGE-EI homepage: http://www.cerge-ei.cz

Editors: Directors of CERGE and EI

Managing editors: Deputy Directors for Research of CERGE and EI

ISSN 1211-3298

ISBN 978-80-7343-130-3 (Univerzita Karlova. Centrum pro ekonomický výzkum

a doktorské studium)

ISBN 978-80-7344-119-7 (Národohospodářský ústav AV ČR, v. v. i.) 
CERGE-EI

P.O.BOX 882

Politických vězňů 7

11121 Praha 1

Czech Republic http://www.cerge-ei.cz 